\title{
COVID-19 and pulmonary fibrosis: therapeutics in clinical trials, repurposing, and potential development
}

\author{
Joowon Yim ${ }^{1}$ Hee Hyun Lim¹ Youngjoo Kwon'1 $^{1}$
}

Received: 21 January 2021 / Accepted: 4 May 2021 / Published online: 28 May 2021

(C) The Pharmaceutical Society of Korea 2021

\begin{abstract}
In 2019, an unprecedented disease named coronavirus disease 2019 (COVID-19) emerged and spread across the globe. Although the rapid transmission of COVID-19 has resulted in thousands of deaths and severe lung damage, conclusive treatment is not available. However, three COVID-19 vaccines have been authorized, and two more will be approved soon, according to a World Health Organization report on December 12, 2020. Many COVID-19 patients show symptoms of acute lung injury that eventually leads to pulmonary fibrosis. Our aim in this article is to present the relationship between pulmonary fibrosis and COVID-19, with a focus on angiotensin converting enzyme-2. We also evaluate the radiological imaging methods computed tomography (CT) and chest X-ray (CXR) for visualization of patient lung condition. Moreover, we review possible therapeutics for COVID-19 using four categories: treatments related and unrelated to lung disease and treatments that have and have not entered clinical trials. Although many treatments have started clinical trials, they have some drawbacks, such as short-term and small-group testing, that need to be addressed as soon as possible.
\end{abstract}

Keywords Pulmonary fibrosis · COVID-19-induced lung damage $\cdot$ Radiological imaging method $\cdot$ Angiotensin converting enzyme- $2 \cdot$ Possible therapeutics

Joowon Yim and Hee Hyun Lim contributed equally to this work.

Youngjoo Kwon

ykwon@ewha.ac.kr

1 College of Pharmacy, Ewha Womans University, 120-750 Seoul, Republic of Korea

\section{Introduction}

Coronavirus disease 2019 (COVID-19) is a disease caused by infection with a novel coronavirus known as severe acute respiratory syndrome coronavirus 2 (SARS-CoV-2). Due to its high transmissibility, approximately 4,880,000 people have been infected with SARS-CoV-2, and millions of people have died $(1,900,000$ dead as of January 8,2021$)$.

The symptoms of COVID-19 infection are generally nonspecific and include fever, dry cough, shortness of breath, and myalgia and are generally related to inflammation of the lower respiratory tract (Lechowicz et al. 2020). Radiological findings from computed tomography (CT) and chest X-ray (CXR) show that the affected pulmonary lobes of COVID-19 patients contain patchy ground-glass opacities (GGOs), fibrous stripes, and irregular solid nodules. Clinically, SARS-CoV-2 infection causes acute lung injury and eventual pulmonary fibrosis, but some aspects of COVID-19 pathogenesis remain unclear (Hadjicharalambous and Lindsay 2020).

In this article, we summarize the causes and molecular mechanisms of pulmonary fibrosis and compare them with those of COVID-19 patients, with a focus on angiotensin converting enzyme-2 (ACE2). We also review radiological imaging methods, CT and CXR, for visualizing the pathophysiology of patient lungs, as well as drugs in clinical use and clinical trials. Given that lung fibrosis is associated with COVID-19, treatments for pulmonary fibrosis are being proposed as treatments for COVID-19, and compounds used to treat other diseases have been suggested as cures for COVID-19. We classify potential treatments based on their relation to lung disease and whether a clinical trial is in process. 


\section{Molecular mechanisms of pulmonary fibrosis}

As summarized in Fig. 1, pulmonary fibrosis is characterized by irreversible scarring and remodeling of the lung and can occur in progression of several lung disorders. Some interstitial lung diseases, for example non-specific interstitial pneumonia, autoimmune-featured interstitial lung disease, and idiopathic pulmonary fibrosis, have a similar onset to COVID-19-induced pulmonary fibrosis. Among them, idiopathic pulmonary fibrosis, a specific form of pulmonary fibrosis with an unknown etiology (Sundarakrishnan et al. 2018), is a chronic and progressive lung disease that leads to irreversible remodeling of lung structure (Selman et al. 2001). Environmental (e.g., smoking, toxic dust, viral infection), microbial, genetic, and epigenetic (e.g., hypomethylation, telomerase, miRNA) factors can damage the alveolar epithelium (Coward et al. 2010; Evans et al. 2016; Chioma and Drake 2017).

Injury to the lung promotes proliferation and activation of type 2 alveolar epithelial cells (AEC2) (Shannon and Hyatt 2004) to cover the exposed alveolar surface and activates provisional matrix (Chambers 2008). In the normal repair process, the provisional matrix slowly disperses, and the lung regains its normal structure and function (Hadjicharalambous and Lindsay 2020). Type 1 alveolar epithelial cells (AEC1) make up $90 \%$ of the alveolar surface. When AEC1s are injured, AEC2s undergo apoptosis and differentiation into AEC1s to re-establish the alveolar epithelium (Selman and Pardo 2006). However, when injury is extensive, AEC2s cannot adequately re-establish the epithelium (Hadjicharalambous and Lindsay 2020), resulting in abnormal tissue repair followed by fibroblast activation, collagen deposition, connective tissue deposition, and angiogenesis (Parimon et al. 2020; Selman and Pardo 2020).

Environmental, microbial, genetic, and epigenetic factors can damage the alveolar epithelium, inducing recurrent microinjuries to lung epithelia and causing an imbalance between profibrotic (e.g., transforming growth factor- $\beta$ [TGF- $\beta$ ], platelet-derived growth factor [PDGF], basic fibroblast growth factor, interleukin-1 [IL-1], tumor necrosis factor- $\alpha[\mathrm{TNF}-\alpha]$ ) and antifibrotic (e.g., keratinocyte growth factor, hepatocyte growth factor, Extracellular biopolymers)

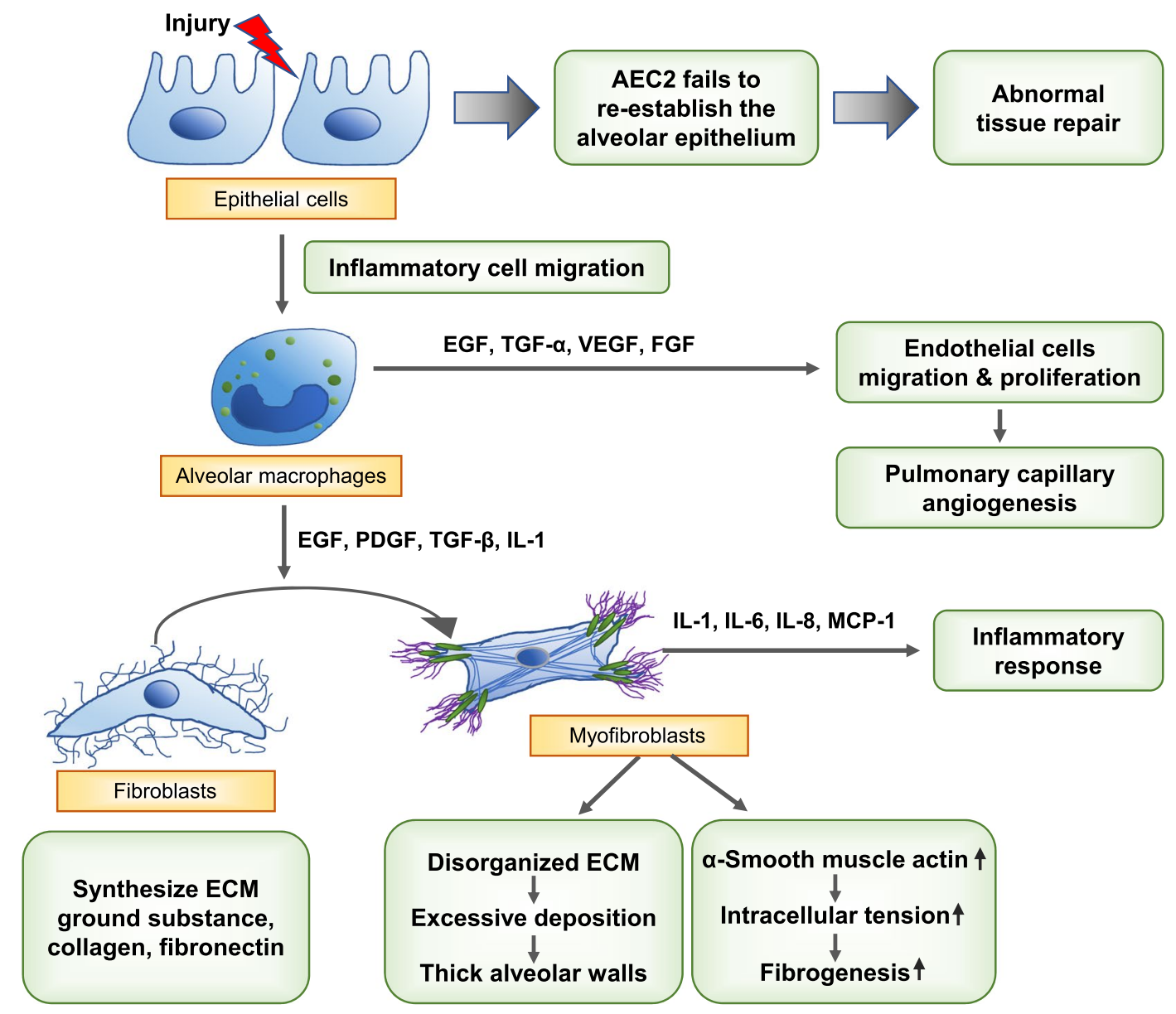

Fig. 1 Summary of pulmonary fibrosis mechanisms 
mediators, which disturbs regeneration of lung epithelia (Kinoshita and Goto 2019). Some cytokines and growth factors produced by alveolar macrophages play an important role in the repair process at the site of injury. The body uses proliferation of bronchiolar stem cells, stimulated by epidermal growth factor (EGF) and transforming growth factor-alpha (TGF- $\alpha$ ), to compensate for the damaged alveolar epithelium (Crosby and Waters 2010). The migration and proliferation of intact endothelial cells lead to pulmonary capillary angiogenesis, in which vascular endothelial growth factor (VEGF) and fibroblast growth factor (FGF) play a central role (Barrientos et al. 2008).

Fibroblasts and myofibroblasts are key cell types in idiopathic pulmonary fibrosis. In the abnormal biochemical environments produced by activated epithelial and endothelial cells, fibroblasts and myofibroblasts are induced and activated to differentiate and proliferate (Upagupta et al. 2018). Fibroblasts in the alveolar interstitium synthesize ECM ground substance, collagen, and fibronectin (Kendall and Feghali-Bostwick 2014). FGF, PDGF, and TGF- $\beta$ stimulate fibroblast migration to the injured site, and those fibroblasts acquire a profibrotic phenotype that is resistant to apoptosis (Yin et al. 2020).

EGF, PDGF, TGF- $\beta$, and IL- 1 proliferate and differentiate fibroblasts into myofibroblasts that perpetuate the fibrotic process. Myofibroblasts secrete IL-1, IL-6, IL-8, and monocyte chemo-attractive protein-1, which influence the inflammatory response (Ojo et al. 2020). ECM produced by myofibroblasts is more disorganized than that of fibroblasts
(Wipff et al. 2007; Sgalla et al. 2018). $\alpha$-Smooth muscle actin enables ECM to contract irreversibly, creating one of the features of fibrogenesis: spatial reorganization of collagen fibrils (Sgalla et al. 2018; Ojo et al. 2020). Excessive deposition of ECM components, such as fibronectin, collagens, and hyaluronan, leads to thick alveolar walls that disturb gas exchange (Wynn 2011; Fernandez and Eickelberg 2012; Kolahian et al. 2016).

\section{Pulmonary fibrosis in COVID-19: focusing on the role of ACE2}

As with other coronavirus infections, acute lung injury and subsequent repair processes are observed in COVID19 patients. In this review, we focus on ACE2, a key entry receptor for SARS-CoV-2. Because ACE2 is a potential receptor for the SARS coronavirus infections that occurred between 2002 and 2003 (Kuba et al. 2006), many studies have examined the correlation between ACE2 and pulmonary fibrosis.

The renin-angiotensin system (RAS) is important in maintaining blood pressure homeostasis and salt balance (Wigen et al. 2020). In addition, RAS helps to regulate inflammation and pulmonary diseases such as idiopathic pulmonary fibrosis, asthma, and chronic obstructive pulmonary disease (Tan et al. 2018).

As summarized in Fig. 2, angiotensin converting enzyme (ACE), which is widely expressed in capillary blood vessels

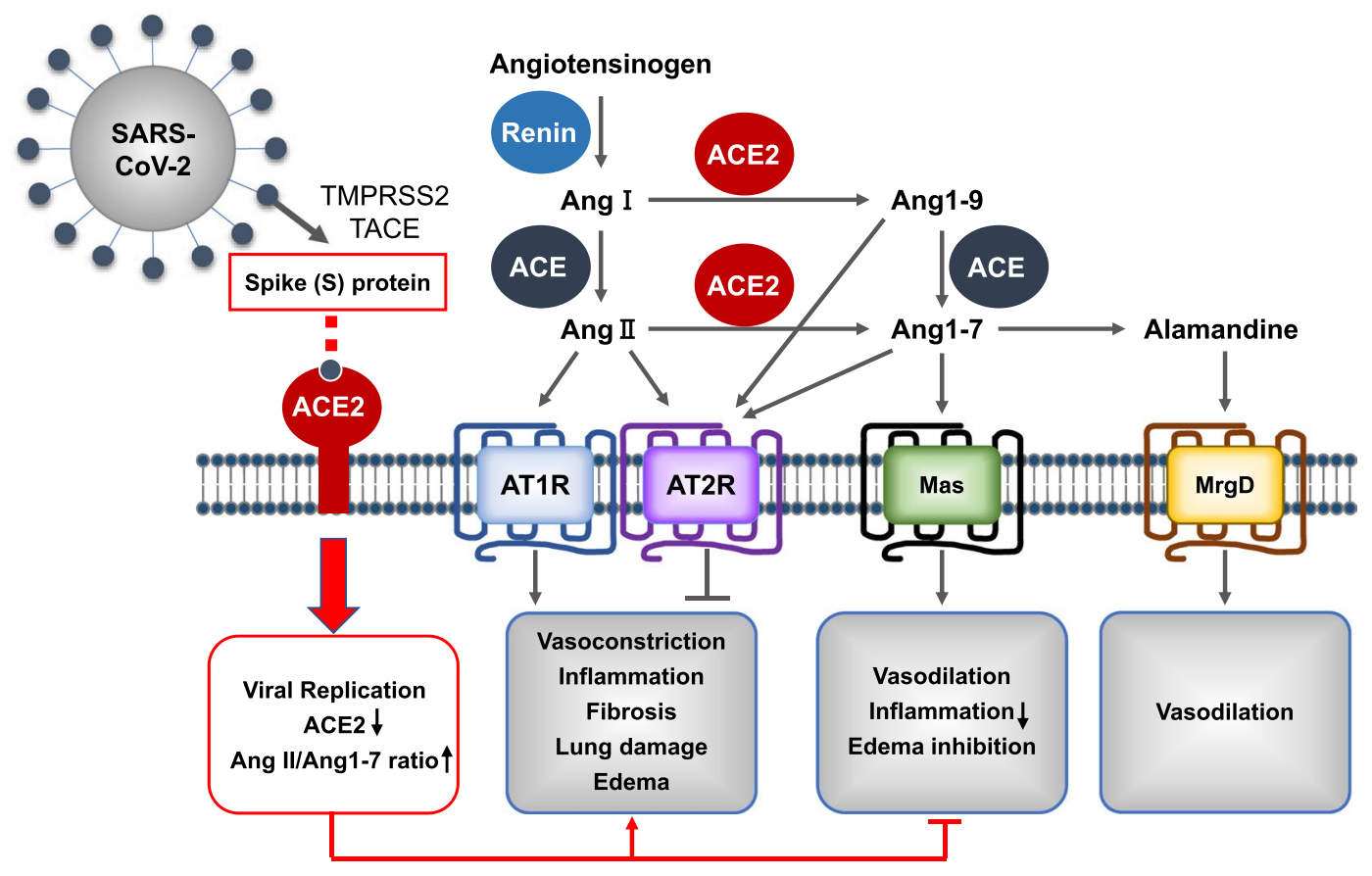

Fig. 2 Summary of ACE function in the renin-angiotensin system and how viral infection affects it 
in the human lung (Studdy et al. 1983), generates octapeptide angiotensin II (Ang II) from decapeptide angiotensin I (Ang I) by cleaving dipeptides from the C-terminus (Corvol et al. 1995; Skeggs et al. 1980). ACE also generates angiotensin 1-7 (Ang 1-7) from angiotensin 1-9 (Ang 1-9). ACE2 removes a single residue from Ang I, generating Ang 1-9, and from Ang II, generating Ang 1-7 (Donoghue et al. 2000). Thus, both ACE and ACE2 function as carboxypeptidases, but they have different substrate specificity (Donoghue et al. 2000; Tipnis et al. 2000; Vickers et al. 2002). Lungs express the angiotensin II type 1 receptor (AT1R), angiotensin II type 2 receptor (AT2R), Mas receptors, and MrgD receptors (Jia 2016; Shrikrishna et al. 2012). Ang II binds to AT1R or AT2R, Ang 1-7 binds to Mas receptors (Errarte et al. 2017), and alamandine binds to MrgD receptors (Kaur et al. 2020a). Through AT1R, Ang II performs biological functions such as promoting vasoconstriction, inflammation, fibrosis, lung damage, and edema (Errarte et al. 2017). Through the Mas receptors, on the other hand, the downstream actions of Ang 1-9 or Ang 1-7 contribute to vasodilation, inflammation reduction, and edema inhibition (Errarte et al. 2017; Wigen et al. 2020). Through MrgD receptors, alamandine, which is the decarboxylated form of Ang 1-7, increases cyclic adenosine monophosphate (cAMP) in endothelial cells, and this leads to vasodilation, as in the case of activation of Mas receptors (Kaur et al. 2020a). Thus, ACE2 functions as a negative regulator of the angiotensin system (Furuhashi et al. 2020).

At the adsorption step in the viral replication cycle, the viral spike (S) protein of SARS-CoV-2 binds to membraneanchored ACE2 of the RAS. Then, the cellular transmembrane protease serine 2 (TMPRSS2) and other related proteases, such as tumor necrosis factor- $\alpha$-converting enzyme, act in S-protein cleavage, which activates the S-protein and results in viral fusion to the host cell membrane (Heurich et al. 2014; Hoffmann et al. 2020). Internalization of ACE2 by SARS-CoV-2 would significantly reduce ACE2 on the cell surface and increase the ratio of Ang II:Ang 1-7 (South et al. 2020). Moreover, the major sources of ACE2 are alveolar type 2 pneumocytes (Bombardini and Picano 2020). Repetitive viral infection of type 2 pneumocytes has a cytolytic effect that results in differentiation toward type 1 pneumocytes and active proliferation of type 1 pneumocytes to replace the damaged alveolar type 2 pneumocytes, which downregulates ACE2 expression (Delpino and Quarleri 2020). Downregulation of ACE2 suppresses the downstream protective activities of RAS, followed by inflammation and pulmonary fibrosis (Wigen et al. 2020).

The plasma level of ACE2 is increased in patients with severe COVID-19 (H. Zhang et al. 2020). Soluble ACE2 that circulates in the blood has a protective effect by binding the virus, disturbing endocytosis (Wigen et al. 2020). Increased soluble ACE2 facilitates the downstream action of Ang 1-7 to counteract inflammation and pulmonary fibrosis, while increased membrane-bound ACE2 can function as a viral entry receptor (Dalan et al. 2020; Leung et al. 2020).

Ang II is a key effector peptide of the RAS system that participates in tissue remodeling and fibrosis by promoting the expression of transforming growth factor- $\beta 1$ (TGF- $\beta 1$ ), which is a profibrotic cytokine that converts fibroblasts into myofibroblasts and deposits collagen (Weber 1997). TGF$\beta 1$ is thought to suppress antioxidant enzymes and thereby increase the ROS level, and ROS induce TGF- $\beta 1$ and its fibrogenic effects (Liu and Desai 2015). Both factors are highly expressed in fibrotic processes. Thus, Ang II contributes to the pathogenesis of pulmonary fibrosis. On the other hand, ACE2 inhibits fibrosis by decreasing the amounts of TGF- $\beta 1$ and $\alpha$-smooth muscle actin in human lungs (Wang et al. 2015). In addition, levels of VEGF, IL-1, and IL-6 are increased in COVID-19 patients, just as they are in idiopathic pulmonary fibrosis patients (George et al. 2020).

\section{Radiological imaging methods to diagnose COVID-19}

A variety of COVID-19 diagnosis methods has been reviewed, including real-time reverse transcriptase PCR (RT-PCR) used with CRISPR-mediated detection or loopmediated isothermal amplification techniques and antibody testing Lamb et al. 2020; Li and Ren 2020; Vandenberg et al. 2020; J. Zhang et al. 2020). We review only radiological imaging methods used to diagnose COVID-19.

Many clinicians use radiological imaging methods, especially for evaluating emergency room patients while waiting for the results of RT-PCR (Cozzi et al. 2020). The two major radiological techniques are CXR and CT. In many study cases, both are used for observing fibrotic changes in COVID-19-induced pulmonary fibrosis (Ojo et al. 2020).

\section{Computed tomography}

The reference standard for COVID-19 diagnosis is RT-PCR. According to the recent COVID-19 literature, CT is primarily being used to address the limitations of RT-PCR. For example, RT-PCR results require 5 to $6 \mathrm{~h}$ to obtain, whereas CT examination results are available much sooner. Moreover, a CT examination can help in early diagnosis of asymptomatic COVID-19 patients and in diagnosing patients with false-negative RT-PCR results. Though RT-PCR is the gold standard for COVID-19 diagnosis, false-negative results are common (Long et al. 2020). Chest CT has high sensitivity for detecting early COVID-19 in patients with later positive conversion of RT-PCR results versus RT-PCR ( $98 \%$ vs. $71 \%$, respectively) (Fang et al. 2020). CT examinations can be used to evaluate therapeutic efficacy and monitor disease 
progression (Ye et al. 2020) because COVID-19 patients with different disease courses and severity show different CT imaging features and patterns. Several COVID-19 case studies have reported typical and atypical CT manifestations: Typical CT symptoms include GGO, consolidation, a reticular pattern, and a crazy paving pattern, whereas relatively atypical CT symptoms are airway changes, pleural changes, a subpleural curvilinear line, fibrosis, vascular enlargement, air bubble sign, nodules, halo sign, reversed halo sign or atoll sign, lymphadenopathy, and pericardial effusion (Ye et al. 2020). Among those symptoms, GGO and consolidation are commonly used for COVID-19 diagnosis, but CT manifestations vary and change over the course of the disease (Okamori et al. 2020).

\section{Chest X-ray}

Although CT has better sensitivity and specificity than CXR, CT has some problems, such as radiation exposure and complex scanner disinfection procedures (Cozzi et al. 2020). On the other hand, CXRs are inexpensive, faster, more widespread, and have a low risk of patient exposure to radiation (Self et al. 2013; Rubin et al. 2020). Therefore, CXR is another useful diagnostic method. The Italian Society of Radiology recommended CXR as a first-line imaging tool (Giovagnoni 2020; Neri et al. 2020), and the American College of Radiologists recommends using portable CXR to decrease the risk of cross infection because the COVID-19 virus has a high infection rate (Rousan et al. 2020).

Many COVID-19 patients show abnormal CXR findings, including peripheral GGO in the lower lobes, consolidation, septal thickening, lymphadenopathy, bronchiectasis, cavitation, and pleural effusion (Bernheim et al. 2020; Caruso et al. 2020; Meng et al. 2020; Salehi et al. 2020; Wong et al. 2020; Yoon et al. 2020).

CXR findings might not reflect early or mild disease (Kim et al. 2020); therefore, normal CXR results do not necessarily rule out COVID-19 infection. Instead, CXR can be used to classify the highest risk patients who will most benefit from hospitalization in an area that lacks hospital beds due to a surging number of patients (Kim et al. 2020).

\section{Therapeutics}

\section{Pharmacological approaches with subdivisions}

\section{Drugs for lung diseases being tried in clinical trials for COVID-19}

Propolis Propolis can be correlated with immune system defenses, reduced viral replication, and anti-inflammatory action in SARS-CoV-2 (Ansorge et al. 2003; Shimizu et al.
2011; Machado et al. 2012; Chan et al. 2013; Hori et al. 2013). Propolis extract and its components can act as an anti-COVID-19 drug by reducing TMPRSS 2 expression and ACE2 anchorage (Kaur et al. 2020a, b). They also immunomodulate monocytes and macrophages by reducing or eliminating IL- $1 \beta$ and IL-6. In addition, they reduce transcription factors such as NF- $\mathrm{KB}$ and JAK2/STAT3 (Shimizu et al. 2011; Asgharpour et al. 2019; Güler et al. 2020; Omar et al. 2020). NF-KB inhibition blocks the production of cytokines in T cells and reduces JAK2/STAT3 signaling, which diminishes inflammation and oxidative stress (Ansorge et al. 2003; Fernandes et al. 2015). Substances found in several types of propolis, caffeine phenethyl ester (CAPE), galangin, chrysin, and caffeic acid, have been shown to inhibit the 3-chymotrypsin-like cysteine enzyme, which is an essential protease for SARS-CoV-2 (Hashem 2020; Kumar et al. 2020). In addition, the Rac protein could be inactivated by CAPE, a component of propolis. Rac inactivation leads to PAK1 inhibition, which represses B cells and T cells. PAK1 is a kinase that is increased during lung inflammation and lung fibrosis (Berretta et al. 2020). PAK1 inhibitors can rescue the immune system and help fight against viruses (Xu et al. 2005; Gorbalenya et al. 2020; Maruta and He 2020). Propolis and its components can help prevent immunosuppression during the initial phases of the disease and decrease the excessive inflammatory response of the host by blocking excess IL-6, IL-2, and JAK signaling in later stages (Nile et al. 2020). One study reported that the use of propolis water extract can reduce the expression of pro-inflammatory cytokines such as TNF- $\alpha$, ICAM-1, IL- 6 , and IL- 8 and increase the protective cytokine IL-10 (Qin et al. 2020). These benefits of propolis have triggered a clinical trial of Brazilian green propolis extract for treatment of COVID19 patients in Brazil (https://clinicaltrials.gov/ct2/ show/ NCT04480593) (Berretta et al. 2020).

CD147 inhibitor CD147 is a receptor for SARS-CoV-2 host cell invasion (K. Wang et al. 2020; Yan et al. 2020). Therefore, a phase 2 clinical trial to prevent COVID-19 by blocking CD147, and thereby entry of the virus, is underway in China (Ulrich and Pillat 2020). The study is testing a humanized form of anti-CD147, Meplazumab, which is specific for CD147, suggesting that CD147 could be a target for preventing COVID-19 (K. Wang et al. 2020). A relationship has been reported between CD147 upregulation and conditions such as diabetes and asthma, so Meplazumab might also prevent diabetes and its complications (Bao et al. 2010; Moheimani et al. 2018). CD147 exists in several types of pulmonary cells, including type 2 pneumocytes and macrophages at the edge of fibrotic regions. Anti-CD147 antibodies block the differentiation and proliferation of fibroblasts into myofibroblasts that are induced by TGF- $\beta 1$ (Guillot et al. 2006). Thus, 
blocking CD147 could prevent pulmonary fibrosis caused by COVID-19 (Ulrich and Pillat 2020).

Low-molecular weight heparin (LMWH) LMWH treatment for COVID-19 is in randomized clinical trials (NCT04366960). Coagulation and D-dimers can determine the severity of the pulmonary diseases that follow COVID19 infection (Di Perri 2020). In some studies, patients taking heparin had lower mortality rates and higher level of D-dimer than control patients (Beigel et al. 2020). Heparin also blocks SARS-CoV-2 from binding to the ACE2 receptor and downregulates IL-6, which can trigger the cytokine storm (Mummery and Rider 2000; Atallah et al. 2020; Kaur et al. 2020a). Dosing and timing are controversial, but the clinical trials currently underway might clarify these aspects (Di Perri 2020).

Montelukast Montelukast, which strongly antagonizes the cysteinyl leukotriene receptor, is in clinical trial for COVID-19 treatment (NCT04389411). It has anti-inflammatory effects and can block the function of cysLT, such as the cytokine production that is one of the main features of COVID-19 infection (Fidan and Aydoğdu 2020). Some montelukast results (high doses, i.v. administration) show a decrease in protein expression of cysteinyl leukotriene, IL-4, IL-5, and IL-13 in the lungs and an antiinflammatory effect caused by down-regulation of T-helper 2 cytokines. The anti-inflammatory effect of high-dose montelukast has been demonstrated in asthma (Wu et al. 2003). Montelukast also blocks bradykinin-induced airway hypersensitivity, which causes a cough associated with ACE inhibition. The mechanism remains uncertain, but it is thought to affect the production of the ACE receptor, which is a receptor for SARS-CoV-2 (Bisgaard et al. 2008; Noor et al. 2011; Kaur et al. 2020a). Therefore, montelukast could be an effective therapeutic for COVID-19.

Phosphodiesterase (PDE) inhibitors PDE5 inhibitors such as sildenafil could be a targeted treatment for COVID-19 and other lung diseases. PDE5 is primarily expressed in the lungs (Giorgi et al. 2020; Isidori et al. 2020). PDE5 inhibition can reduce the cytokine storm by reducing the release of pro-inflammatory cytokines because it can downregulate angiotensin II receptor type 1 (AT-1) receptor (Isidori et al. 2020). PDE5 inhibitors are safe and have some benefits in type 2 diabetes patients, such as reducing disease-related mortality (Giannetta et al. 2014). Sildenafil can prevent clotting and thrombotic complications by blocking the transformation of endothelial and smooth muscles into mesenchymal cells in pulmonary arteries (Isidori et al. 2020). The clinical trial process for the use of PDE5 inhibitors in COVID-19 treatment could be facilitated by the various clinical trials already conducted for PDE5 inhibitors in a variety of diseases (Phillips 2020).
Drugs for other diseases being tired in clinical trials of COVID-19

Novavax A phase III trial of NVX-CoV2373 (Novavax), a recombinant SARS-CoV-2 nanoparticle vaccine, recently has started in the UK (Du et al. 2009; Keech et al. 2020; Tai et al. 2020). Novavax contains the trimeric full-length spike glycoproteins of SARS-CoV-2 and the adjuvant MatrixM1 (Du et al. 2009; Giannetta et al. 2014; Bengtsson et al. 2016; Chen et al. 2020; Giorgi et al. 2020; Isidori et al. 2020; Keech et al. 2020; Phillips 2020; Tai et al. 2020). Novavax blocks SARS-CoV-2 infection in rodent and other non-human models by inducing a high titer of antibody IgG, which inhibits binding to human ACE2 and neutralizes the virus (Kaur et al. 2020a). It also produces multifunctional $\mathrm{CD} 4+$ and CD8 + T cell responses, mainly with the T helper phenotype (Mandolesi et al. 2020; Tian et al. 2020). The protective mechanism against COVID-19 is not clear, but the neutralizing antibodies appear to be related to the protection (Mulligan et al. 2020). During phase I and II trials, no critical side effects were observed, indicating the safety of Novavax (Keech et al. 2020). Although the previous trials were small and had short follow-up periods, Novavax could be an effective vaccine against COVID-19.

Melatonin Many studies suggest that melatonin could be an effective treatment for COVID-19. Recently, a clinical trial has started in ICU patients with COVID-19 (NCT04568863) (Acuña-Castroviejo et al. 2020). The cytokine storm of COVID-19 is associated with activation of the NF- $\mathrm{NB}$ pathway and release of cytokines such as IL-1 $\beta$ (Merad and Martin 2020; Tay et al. 2020). Melatonin can act as an anti-inflammatory molecule because it can block $N F-\kappa B$ activation and the positive feedback of IL-1 $\beta$. Studies also found that the main target of melatonin is mitochondria, and that melatonin can maintain mitochondria and homeostasis in all organs and tissues of mice with sepsis (Martín et al. 2000; Escames et al. 2003). Moreover, it can rescue the lungs from oxidative damage caused by age (AcuñaCastroviejo et al. 2012). Because the inflammatory response of sepsis is similar to that of COVID-19, melatonin could be an effective treatment for COVID-19 (Keech et al. 2020).

Remdesivir Remdesivir is a promising drug for COVID19. Remdesivir, an adenosine analog, is changed to its active form (GS-443,902) and selectively blocks the viral RNA-dependent RNA polymerase (Lo et al. 2017; Sheahan et al. 2017; Agostini et al. 2018; Agency 2020). This drug has effects in many diseases, including SARS-CoV-1 and MERS-CoV infections (Sheahan et al. 2017, 2020; de Wit et al. 2020; Gordon et al. 2020). Some reports discuss the anti-viral and clinical effects of remdesivir (Singh et al. 2020). In addition, remdesivir can inhibit epithelial cells in human nasal and bronchial airways (Pizzorno 2020). Due to its many effects and efficacy, the United States Food Drug 
Administration has granted an Emergency Use Authorization to remdesivir for COVID-19 treatment (Singh et al. 2020). However, many clinical trials are ongoing, and its safety must be validated.

Chloroquine and hydroxychloroquine Chloroquine and hydroxychloroquine can be used to treat COVID-19 (Meo et al. 2020). Chloroquine increases endosomal $\mathrm{pH}$ and inhibits virus-cell fusion and viral infection. It also blocks virus-cell binding by inhibiting glycosylation of SARS-CoV receptors (Vincent et al. 2005). Many clinical trials have examined their safety and efficacy. Chloroquine can shorten disease progression by blocking degeneration to pneumonia, enhancing lung imaging findings, and accelerating virus-negative conversion (Gao et al. 2020). However, in vitro studies have shown that hydroxychloroquine is more effective than chloroquine at inhibiting SARS-CoV-2 (Yao et al. 2020). The United States Food Drug Administration permits the use of hydroxychloroquine and chloroquine to treat COVID-19 (Diamond 2020).

BTK/ITK dual inhibitors Bruton's tyrosine kinase (BTK)/ inducible T-cell kinase (ITK) dual inhibitors can treat COVID-19 (McGee et al. 2020). COVID-19 patients have elevated levels of blood neutrophils and cytokines, and inhibiting that immune response can be therapeutic (D. Wang et al. 2020). BTK, which is prevalent in B cells, elevates proinflammatory cytokines, including IFN- $\beta$, by means of various signaling pathways for TLRs, macrophages, and dendritic cells (Weber et al. 2017). In patients with severe COVID-19, NF- $\kappa B$ is elevated, which mediates the TLR/ BTK signaling pathway (Liao et al. 2020). BTK also is associated with production of inflammatory cytokines, such as active pro-IL-1 $\beta$ (Weber et al. 2017). Therefore, the BTK inhibitors acalabrutinib, zanubrutinib, and ibrutinib are in clinical trials as treatments for COVID-19. Also, ITK, which is prevalent in $\mathrm{T}$ cells, modulates activation of $\mathrm{CD} 4+$ and $\mathrm{CD} 8+\mathrm{T}$ cells and production of cytokines (Solouki et al. 2019). Some studies suggest that the Th1 response is important in regulating respiratory coronaviruses because Th1polarized SARS-CoV-2-specific memory T cell responses are observed in COVID-19 patients (Dong et al. 2020; Grifoni et al. 2020; Neidleman et al. 2020; Weiskopf 2020). ITK signaling results in elevation of the Fas ligand (FasL), which leads to activation-induced $\mathrm{T}$ cell death (Long et al. 2017). Inhibition of ITK signaling elevates the level of CD4 $+\mathrm{T}$ cells and is effective for treating COVID-19 (Sun et al. 2015).

\section{Potential drugs for COVID-19 not yet in clinical trials}

Galectin-3 (Gal3) inhibitors One of the principle phases of COVID-19 is the hyperinflammatory phase, during which immune cells release gal3 (Burguillos et al. 2015; BozaSerrano et al. 2019). There have been reports of elevated gal3 level in proliferative $\mathrm{T}$ cells in patients with COVID19 (Liao et al. 2020). Gal3 is a carbohydrate-binding protein expressed by macrophages and epithelial and alveolar cells in the lungs (Reyfman et al. 2019). Gal3 binds to and activates TLR4 and TREM2, reflecting its association with lung diseases and fibrosis (Burguillos et al. 2015; Boza-Serrano et al. 2019). TREM2, expressed by macrophages, is a marker related to the fibrotic process (Liao et al. 2020), and TLR, which is critical for antiviral response, leads to strong inflammation associated with interferon-related genes, interleukins, chemokines, and gal 3 expression (Guo et al. 2020). Some gal3 inhibitors have been shown to suppress the release of IL- 1 , IL- 6 , and TNF- $\alpha$, which are related to the inflammatory phase of COVID-19 (Boza-Serrano et al. 2014, 2019). Gal3 shares an extracellular domain with ACE2, the receptor for SARS-CoV-2 infection, indicating that gal3 inhibitors bind to ACE2 (Clarke and Turner 2012; Kovak et al. 2014; Kaur et al. 2020a). TD139, a gal3 inhibitor provided by Galecto Biotech, has been shown to be safe and effective against idiopathic lung fibrosis (NCT04473053), and clinical trials could be performed in the presence of a clinically tolerable gal3 inhibitor (GarciaRevilla et al. 2020).

Poly-(ADP-ribose) polymerase inhibitor (PARPi) PARPi could be an effective treatment for COVID-19 because it can prevent cytokine storms (macrophage overactivation) and protect cells against death (Curtin et al. 2020). Previous studies have suggested that SARS-CoV-2 infection induces PARP activation, which is increased in the lung tissue of asthmatic patients, and different preclinical animal models have indicated that PARPi could reduce the lung fibrosis induced by SARS-CoV-2 lung inflammation (Ghonim, Pyakurel, Ibba, Al-Khami, et al. 2015; Carlile et al. 2016). The cytokine storm, a major reason for mortality in COVID19, results in multi-organ failure (Mehta et al. 2020). Many studies in animal models suggest that PARPi, including olaparib, can reduce IL- 6 and IL-1 $\beta$ expression in many organs, including the lungs (Mabley et al. 2001; Liaudet et al. 2002; Pagano et al. 2007; Kim et al. 2008; Ghonim, Pyakurel, Ibba, Wang, et al. 2015; Sethi et al. 2019; Sahu et al. 2020). Moreover, olaparib has been shown to reduce the level of TNF- $\alpha$ in the lungs in animal models of lung inflammation (Cuzzocrea et al. 2002; Liaudet et al. 2002; Virág et al. 2004; Kim et al. 2008; Sahu et al. 2020). These preclinical studies and results show that PARPi has potential for human applications as a notable potential treatment for COVID-19.

Cobra venom and NNAV Cobrotoxin and $\alpha$-neurotoxin from Naja naja atra venom (NNAV) can be used to prevent and relieve symptoms of COVID-19. Cobrotoxin and $\alpha$-neurotoxin have many pharmacodynamic actions through their binding to nicotinic acetylcholine receptors, which are widely distributed throughout the body (Kuo et al. 1995; 
Lin et al. 2020). NNAV and $\alpha$-neurotoxins can inhibit the cytokine storm through their strong inhibitory effects on inflammation (Lin et al. 2020; L. Zhang et al. 2020). NNAV and cobrotoxin also have immunoprotective activity. CD8 $\mathrm{T}$ cells are increased in COVID-19 patients and their proliferation can be blocked by NNAV and cobrotoxin more than they affect CD4 T cells. NNAV and cobrotoxin also restore the CD4/CD8 ratio (Ganji et al. 2020; Lin et al. 2020). can inhibit lung inflammation, improve lung gas exchange function, and reduce the development of fibrotic lesions in the lung (George et al. 2020; Polak et al. 2020). Cobra venoms were first approved for use by the US Food and Drug Administration in the $1940 \mathrm{~s}$ (Lin et al. 2020).

Tetracyclines Tetracyclines, which are lipophilic antibiotics, may be effective for treating COVID-19. Tetracyclines can permeate lung tissue and might block SARS-CoV-2 replication in the lungs through their anti-inflammatory effects (Sodhi and Etminan 2020). Chemically modified tetracyclines are used to prevent septic shock caused by ARDS, which is a main complication in COVID-19 patients (Griffin et al. 2010). Also, the host matrix metalloproteinase (MMP) complex, which includes zinc, plays an important role in coronavirus survival and cell penetration, adherence, and replication (Humar et al. 2004; Phillips et al. 2017). Tetracyclines can chelate the zinc compounds on MMPs, which can inhibit SARS-CoV-2 replication in the host (Zakeri and Wright 2008). Furthermore, inflammatory cytokines such as TNF- $\alpha$, IL- $1 \beta$, and IL- 6 are increased in patients with severe SARS-CoV-2 (Yoshikawa et al. 2009). The elevation of those cytokines can be inhibited by tetracyclines through NF- $\mathrm{kB}$ pathway suppression, so they can be therapeutics for COVID-19 (Henehan et al. 2017).

Saikosaponins Saikosaponins, especially saikosaponin A, saikosaponin B, and saikosaponin D, are potential treatments for COVID-19 (Bahbah et al. 2020). Saikosaponins have antiviral effects on various viruses. Saikosaponin A decreases the immunopathology of the lung, and saikosaponin B blocks HCoV-229E infection in vitro by inhibiting viral adherence and invasion into cells (Cheng et al. 2006). The immunomodulatory and anti-inflammatory activities of saikosaponin A might block increases in inflammatory mediators and cytokines, such as TNF- $\alpha, \mathrm{COX}-2$, and interleukins, which are found in patients with severe COVID-19 (Yuan et al. 2017). Moreover, saikosaponin A binds highly to the ACE-2 receptor, which is the main receptor for SARSCoV-2 infection (Kaur et al. 2020a; Yan et al. 2020).

\section{Non-pharmacological approaches}

Extracorporeal membrane oxygenation (ECMO) A case report described how a 31-year-old pregnant woman at 35 weeks of gestation received ECMO treatment and was cured of COVID-19 infection (Hou et al. 2020). ECMO improves gas exchange and relieves ventilator-associated lung injury in acute respiratory distress syndrome (ARDS) treatment, so use of ECMO can temporarily restore pulmonary function (Davies et al. 2009). However, the role of ECMO in COVID-19 patients with respiratory failure remains unclear. Many COVID-19 patients who were treated with ECMO have died (X. Li et al. 2020). The leading causes of death in COVID-19 patients are bleeding and infection, which lead to lymphocyte and IL-6 elevation (Henry 2020; Henry and Lippi 2020). Although ECMO has some safety issues, it can ameliorate lung dysfunction, and one case report shows its potential for treating COVID-19 patients.

Stem cells Stem cell therapy, especially mesenchymal stem cell (MSC)-related therapy, could be a treatment for COVID-19. MSCs have anti-inflammatory signaling and immunomodulatory properties, making them effective against diseases such as COVID-19 (Z. Li et al. 2020). The immunomodulatory ability of MSCs can reduce the cytokine storm and prevent the T cell imbalance caused by COVID-19 infection (Uccelli and de Rosbo 2015; Fayyad-Kazan et al. 2016; Leng et al. 2020). MSCs also act on antigen-presenting cells such as dendritic cells and macrophages, modulating ARDS, anti-viral immunity, and tissue healing in COVID-19 patients ( $\mathrm{Z}$. Li et al. 2020; Merad and Martin 2020; Zhou et al. 2020). Clinical trials of stem cell therapies for COVID-19 are ongoing in many countries. The results from preclinical and early clinical studies have demonstrated their efficacy and direct MSC relocation to the lungs, which could help treat pulmonary diseases in patients with COVID-19. However, the safety and efficacy of stem cell therapy should be further demonstrated through continuing clinical studies ( $\mathrm{Z}$. Li et al. 2020).

Clustered regularly interspaced short palindromic repeats (CRISPR) CRISPR, which is a tool for gene editing, can be used as a COVID-19 treatment (Straiton 2020). Its editing tool can be applied to block SARS-CoV-2 replication and induce damage to the viral RNA. Also, prophylactic antiviral CRISPR in human cells (PAC-MAN) contains a gRNA strand that is particular to SARS-CoV-2 genome nucleotide sequences (Abbott et al. 2020). Still, there are many problems to solve, the most challenging of which is delivery of its bulky components into cells (Kobie 2020). Synthetic, nontoxic peptide lipitoids are a possible solution to this because they can encapsulate nucleotides as nanoparticles. When lipitoids and PAC-MAN technology were combined, they decreased the SARS-CoV-2 level in a sample of human epithelial lung cells by more than 90\% (Laboratory 2020). More studies are required, but existing results reflect the potential of CRISPR as a treatment for COVID-19. 


\section{Conclusions}

COVID-19 is an unprecedented disease that spreads rapidly and has caused many infections and deaths worldwide. Many COVID-19 patients suffer lung damage, including pulmonary fibrosis in severe cases. We described the causes and molecular mechanisms of pulmonary fibrosis and compared them with reports about SARS-CoV-2 patients. We specifically focused on the relationship between ACE2 and pulmonary fibrosis in COVID-19 patients. In many COVID-19 patients, decreased ACE2 expression is observed, which leads to decreased Ang 1-7 levels and increased Ang II activity, which can produce pulmonary fibrosis (Delpino and Quarleri 2020). Although the molecular mechanisms of pulmonary fibrosis in COVID-19 patients remain unclear, the involvement of ACE2 is promising.

We reviewed the use of radiological imaging methods CT and CXR to show the pathophysiology of patient lungs, and we inferred that they can be used for diagnosing lung diseases in COVID-19 patients.

We also provided an overview of some therapeutics for COVID-19 patients. We classified treatments as those related or unrelated to lung diseases and those that have or have not entered clinical trials. Many therapeutics are in clinical trials and showing good potential as COVID-19 treatments, and many of those are used to treat other diseases. However, even in previously approved treatments, dosing, safety, and efficacy for COVID-19 patients should be clearly identified. Clinical trials with larger populations and longer periods are needed to verify effectiveness and safety. A great deal of further research is needed, but we expect the detailed mechanisms of SARS-CoV-2 to be elucidated soon.

Acknowledgements This study was supported by a grant from National Research Foundation of Korea (NRF) grants funded by the Korean government (MSIT) (2018R1A5A2025286).

\section{Declarations}

Conflict of interest The authors have no conflicts of interests to declare.

\section{References}

Abbott TR, Dhamdhere G, Liu Y, Lin X, Goudy L, Zeng L, Chemparathy A, Chmura S, Heaton NS, Debs R (2020) Development of CRISPR as an antiviral strategy to combat SARS-CoV-2 and influenza. Cell. https://doi.org/10.1016/j.cell.2020.04.020

Acuña-Castroviejo D, Carretero M, Doerrier C, López LC, GarcíaCorzo L, Tresguerres JA, Escames G (2012) Melatonin protects lung mitochondria from aging. AGE 34(3):681-692. https://doi. org/10.1007/s11357-011-9267-8

Acuña-Castroviejo D, Escames G, Figueira JC, de la Oliva P, Borobia AM, Acuña-Fernández C (2020) Clinical trial to test the efficacy of melatonin in COVID-19. J Pineal Res 69(3):e12683. https:// doi.org/10.1111/jpi.12683

Agency EM (2020) Summary on compassionate use Remdesivir Gilead. In: European Medicines Agency Amsterdam, The Netherlands. Publishing The European Medicines Agency. https:// www.ema.europa.eu/en/documents/other/summary-compassion ate-use-remdesivir-gilead_en.pdf. Accessed 01 May 2021

Agostini ML, Andres EL, Sims AC, Graham RL, Sheahan TP, Lu X, Smith E, Case J, Feng J, Jordan R (2018) Coronavirus susceptibility to the antiviral remdesivir (GS-5734) is mediated by the viral polymerase and the proofreading exoribonuclease. MBio 9:e00221-18. https://doi.org/10.1128/mBio.00221-18

Ansorge S, Reinhold D, Lendeckel U (2003) Propolis and some of its constituents down-regulate DNA synthesis and inflammatory cytokine production but induce TGF- $\beta 1$ production of human immune cells. Z Nat C 58(7-8):580-589. https://doi.org/10.1515/ znc-2003-7-823

Asgharpour F, Moghadamnia AA, Motallebnejad M, Nouri HR (2019) Propolis attenuates lipopolysaccharide-induced inflammatory responses through intracellular ROS and NO levels along with downregulation of IL- $1 \beta$ and IL- 6 expressions in murine RAW 264.7 macrophages. J Food Biochem 43(8):e12926. https://doi. org/10.1111/jfbc.12926

Atallah B, Mallah SI, AlMahmeed W (2020) Anticoagulation in COVID-19. Eur Heart J. https://doi.org/10.1093/ehjcvp/pvaa036

Bahbah EI, Negida A, Nabet MS (2020) Purposing Saikosaponins for the treatment of COVID-19. Med Hypotheses 140:109782. https://doi.org/10.1016/j.mehy.2020.109782

Bao W, Min D, Twigg SM, Shackel N, Warner FJ, Yue DK, Mclennan SV (2010) Monocyte CD147 is induced by advanced glycation end products and high glucose concentration: possible role in diabetic complications. Am J Physiol 299(5):C1212-C1219. https://doi.org/10.1152/ajpcell.00228.2010

Barrientos S, Stojadinovic O, Golinko MS, Brem H, Tomic-Canic M (2008) Growth factors and cytokines in wound healing. Wound Repair Regen 16(5):585-601. https://doi.org/10.1111/j.1524475X.2008.00410.X

Beigel JH, Tomashek KM, Dodd LE, Mehta AK, Zingman BS, Kalil AC, Hohmann E, Chu HY, Luetkemeyer A, Kline S (2020) Remdesivir for the treatment of Covid-19-preliminary report. N Engl J Med. https://doi.org/10.1056/NEJMoa2007764

Bengtsson KL, Song H, Stertman L, Liu Y, Flyer DC, Massare MJ, Xu R-H, Zhou B, Lu H, Kwilas SA (2016) Matrix-M adjuvant enhances antibody, cellular and protective immune responses of a Zaire Ebola/Makona virus glycoprotein (GP) nanoparticle vaccine in mice. Vaccine 34(16):1927-1935. https://doi.org/10. 1016/j.vaccine.2016.02.033

Bernheim A, Mei X, Huang M, Yang Y, Fayad ZA, Zhang N, Diao K, Lin B, Zhu X, Li K, Li S, Shan H, Jacobi A, Chung M (2020) Chest CT findings in coronavirus disease-19 (COVID-19): relationship to duration of infection. Radiology 295(3):200463. https://doi.org/10.1148/radiol.2020200463

Berretta AA, Silveira MAD, Capcha JMC, De Jong D (2020) Propolis and its potential against SARS-CoV-2 infection mechanisms and COVID-19 disease. Biomed Pharmacother. https://doi.org/ 10.1016/j.biopha.2020.110622

Bisgaard H, Flores-Nunez A, Goh A, Azimi P, Halkas A, Malice M-P, Marchal J-L, Dass SB, Reiss TF, Knorr BA (2008) Study of montelukast for the treatment of respiratory symptoms of postrespiratory syncytial virus bronchiolitis in children. Am J Respir Crit Care Med 178(8):854-860. https://doi.org/10.1164/rccm. 200706-910OC

Bombardini T, Picano E (2020) Angiotensin-Converting Enzyme 2 as the Molecular Bridge Between Epidemiologic and Clinical Features of COVID-19. Can J Cardiol 36(5):784.e781-784.e782. https://doi.org/10.1016/j.cjca.2020.03.026 
Boza-Serrano A, Reyes JF, Rey NL, Leffler H, Bousset L, Nilsson U, Brundin P, Venero JL, Burguillos MA, Deierborg T (2014) The role of Galectin-3 in $\alpha$-synuclein-induced microglial activation. Acta Neuropathol Commun 2(1):1-14. https://doi.org/ 10.1186/s40478-014-0156-0

Boza-Serrano A, Ruiz R, Sanchez-Varo R, García-Revilla J, Yang Y, Jimenez-Ferrer I, Paulus A, Wennström M, Vilalta A, Allendorf D (2019) Galectin-3, a novel endogenous TREM2 ligand, detrimentally regulates inflammatory response in Alzheimer's disease. Acta Neuropathol 138(2):251-273. https://doi.org/10. 1007/s00401-019-02013-z

Burguillos MA, Svensson M, Schulte T, Boza-Serrano A, GarciaQuintanilla A, Kavanagh E, Santiago M, Viceconte N, OlivaMartin MJ, Osman AM (2015) Microglia-secreted galectin-3 acts as a toll-like receptor 4 ligand and contributes to microglial activation. Cell Rep 10(9):1626-1638. https://doi.org/10. 1016/j.celrep.2015.02.012

Carlile GW, Robert R, Matthes E, Yang Q, Solari R, Hatley R, Edge CM, Hanrahan JW, Andersen R, Thomas DY (2016) Latonduine analogs restore F508del-cystic fibrosis transmembrane conductance regulator trafficking through the modulation of Poly-ADP ribose polymerase 3 and poly-ADP ribose polymerase 16 activity. Mol Pharmacol 90(2):65-79. https://doi.org/10. 1124/mol.115.102418

Caruso D, Zerunian M, Polici M, Pucciarelli F, Polidori T, Rucci C, Guido G, Bracci B, De Dominicis C, Laghi A (2020) Chest CT features of COVID-19 in Rome, Italy. Radiology 296(2):E79E85. https://doi.org/10.1148/radiol.2020201237

Chambers RC (2008) Abnormal wound healing responses in pulmonary fibrosis: focus on coagulation signalling. Eur Respir Rev 17:130-137. https://doi.org/10.1183/09059180.00010905

Chan GC-F, Cheung K-W, Sze DM-Y (2013) The immunomodulatory and anticancer properties of propolis. Clin Rev Allergy Immunol 44(3):262-273. https://doi.org/10.1007/s12016-012-8322-2

Chen Y, Chen W, Zhou J, Sun C, Lei Y (2020) Large pulmonary cavity in COVID-19 cured patient case report. Ann Palliat Med. https://doi.org/10.21037/apm-20-452

Cheng PW, Ng LT, Chiang LC, Lin CC (2006) Antiviral effects of saikosaponins on human coronavirus 229E in vitro. Clin Exp Pharmacol Physiol 33(7):612-616. https://doi.org/10.1111/j. 1440-1681.2006.04415.x

Chioma OS, Drake WP (2017) Role of microbial agents in pulmonary fibrosis. Yale J Biol Med 90(2):219-227

Clarke NE, Turner AJ (2012) Angiotensin-converting enzyme 2: the first decade. Int J Hypertens 2012:307315. https://doi.org/10. $1155 / 2012 / 307315$

Corvol P, Williams TA, Soubrier F (1995) Peptidyl dipeptidase A: angiotensin I-converting enzyme. Methods Enzymol 248:283305. https://doi.org/10.1016/0076-6879(95)48020-x

Coward WR, Saini G, Jenkins G (2010) The pathogenesis of idiopathic pulmonary fibrosis. Ther Adv Respir Dis 4(6):367-388. https://doi.org/10.1177/1753465810379801

Cozzi D, Albanesi M, Cavigli E, Moroni C, Bindi A, Luvara S, Lucarini S, Busoni S, Mazzoni LN, Miele V (2020) Chest X-ray in new Coronavirus Disease 2019 (COVID-19) infection: findings and correlation with clinical outcome. Radiol Med 125(8):730-737. https://doi.org/10.1007/s11547-020-01232-9

Crosby LM, Waters CM (2010) Epithelial repair mechanisms in the lung. Am J Physiol Lung Cell Mol Physiol 298(6):L715-L731. https://doi.org/10.1152/ajplung.00361.2009

Curtin N, Bányai K, Thaventhiran J, Le Quesne J, Helyes Z, Bai P (2020) Repositioning PARP inhibitors for SARS-CoV-2 infection(COVID-19); a new multi-pronged therapy for acute respiratory distress syndrome? Br J Pharmacol 177(16):36353645. https://doi.org/10.1111/bph.15137
Cuzzocrea S, McDonald MC, Mazzon E, Dugo L, Serraino I, Threadgill M, Caputi AP, Thiemermann C (2002) Effects of 5-aminoisoquinolinone, a water-soluble, potent inhibitor of the activity of poly (ADP-ribose) polymerase, in a rodent model of lung injury. Biochem Pharmacol 63(2):293-304. https://doi.org/10. 1016/S0006-2952(01)00864-4

Dalan R, Bornstein SR, El-Armouche A, Rodionov RN, Markov A, Wielockx B, Beuschlein F, Boehm BO (2020) The ACE-2 in COVID-19: Foe or Friend? Horm Metab Res 52(5):257-263. https://doi.org/10.1055/a-1155-0501

Davies A, Jones D, Bailey M, Beca J, Bellomo R, Blackwell N, Forrest P, Gattas D, Granger E, Herkes R (2009) Australia and New Zealand Extracorporeal Membrane Oxygenation (ANZ ECMO) Influenza Investigators. Extracorporeal membrane oxygenation for 2009 influenza A (H1N1) acute respiratory distress syndrome. Jama 302(17):1888-1895. https://doi.org/ 10.1001/jama.2009.1535

de Wit E, Feldmann F, Cronin J, Jordan R, Okumura A, Thomas T, Scott D, Cihlar T, Feldmann H (2020) Prophylactic and therapeutic remdesivir (GS-5734) treatment in the rhesus macaque model of MERS-CoV infection. Proc Natl Acad Sci 117(12):6771-6776. https://doi.org/10.1073/pnas.1922083117

Delpino MV, Quarleri J (2020) SARS-CoV-2 Pathogenesis: imbalance in the renin-angiotensin system favors lung fibrosis. Front Cell Infect Microbiol 10:340. https://doi.org/10.3389/fcimb. 2020.00340

Di Perri G (2020) The rationale for Low-Molecular Weight Heparin (LMWH) use in SARS-CoV-2 infection. Le Infez Med 28. https://www.scopus.com/inward/record.uri?eid=2-s2.0-85086 606157\& partnerID $=40 \&$ md5 $=7651 \mathrm{e} 4 \mathrm{dc} 0570 \mathrm{fb} 0 \mathrm{~d} 6 \mathrm{~b} 10 \mathrm{f} 3 \mathrm{cbe}$ 0b75b79. Accessed 01 May 2021

Diamond D (2020) FDA issues emergency authorization of antimalaria drug for coronavirus care. Publishing Politico. https:// www.politico.com/news/2020/03/29/fda-emergency-authorizat ion-anti-malaria-drug-155095. Accessed 01 May 2021

Dong T, Peng Y, Mentzer AJ, Liu G, Yao X, Yin Z, Dong D, Dejnirattisai W, Turtle L, Rostron T (2020) Broad and strong memory CD4 + and CD8 + T cells induced by SARS-CoV-2 in UK convalescent COVID-19 patients. BioRxiv. https://doi. org/10.1038/s41590-020-0782-6

Donoghue M, Hsieh F, Baronas E, Godbout K, Gosselin M, Stagliano N, Donovan M, Woolf B, Robison K, Jeyaseelan R, Breitbart RE, Acton S (2000) A novel angiotensin-converting enzymerelated carboxypeptidase (ACE2) converts angiotensin I to angiotensin 1-9. Circ Res 87(5):E1-9. https://doi.org/10.1161/ 01.res.87.5.e1

Du L, He Y, Zhou Y, Liu S, Zheng B-J, Jiang S (2009) The spike protein of SARS-CoV - a target for vaccine and therapeutic development. Nat Rev Microbiol 7(3):226-236. https://doi.org/ 10.1038/nrmicro2090

Errarte P, Beitia M, Perez I, Manterola L, Lawrie CH, Solano-Iturri JD, Calvete-Candenas J, Unda M, Lopez JI, Larrinaga G (2017) Expression and activity of angiotensin-regulating enzymes is associated with prognostic outcome in clear cell renal cell carcinoma patients. PLoS One 12(8):e0181711. https://doi.org/10. 1371/journal.pone.0181711

Escames G, León J, Macías M, Khaldy H, Acuña-Castroviejo D (2003) Melatonin counteracts lipopolysaccharide-induced expression and activity of mitochondrial nitric oxide synthase in rats. FASEB J 17(8):1-22. https://doi.org/10.1096/fj.020692fje

Evans CM, Fingerlin TE, Schwarz MI, Lynch D, Kurche J, Warg L, Yang IV, Schwartz DA (2016) Idiopathic pulmonary fibrosis: a genetic disease that involves mucociliary dysfunction of the peripheral airways. Physiol Rev 96(4):1567-1591. https://doi. org/10.1152/physrev.00004.2016 
Fang Y, Zhang H, Xie J, Lin M, Ying L, Pang P, Ji W (2020) Sensitivity of Chest CT for COVID-19: comparison to RT-PCR. Radiology 296(2):E115-E117. https://doi.org/10.1148/radiol.2020200432

Fayyad-Kazan H, Faour WH, Badran B, Lagneaux L, Najar M (2016) The immunomodulatory properties of human bone marrowderived mesenchymal stromal cells are defined according to multiple immunobiological criteria. Inflamm Res 65(6):501-510. https://doi.org/10.1007/s00011-016-0933-2

Fernandes MHV, Ferreira LDN, Vargas GDA, Fischer G, Hübner SDO (2015) Effect of water extract from brown propolis on production of ifn- $\gamma$ after immunization against canine parvovirus (CPV) and canine coronavirus (CCoV). Cienc Anim Bras 16(2). https://doi. org/10.1590/1089-6891v16i223458

Fernandez IE, Eickelberg O (2012) New cellular and molecular mechanisms of lung injury and fibrosis in idiopathic pulmonary fibrosis. Lancet 380(9842):680-688. https://doi.org/10.1016/S01406736(12)61144-1

Fidan C, Aydoğdu A (2020) As a potential treatment of COVID-19: Montelukast. Med Hypotheses 142:109828. https://doi.org/10. 1016/j.mehy.2020.109828

Furuhashi M, Moniwa N, Takizawa H, Ura N, Shimamoto K (2020) Potential differential effects of renin-angiotensin system inhibitors on SARS-CoV-2 infection and lung injury in COVID19. Hypertens Res 43(8):837-840. https://doi.org/10.1038/ s41440-020-0478-1

Ganji A, Farahani I, Khansarinejad B, Ghazavi A, Mosayebi G (2020) Increased expression of CD8 marker on T-cells in COVID-19 patients. Blood Cells Mol Dis 83:102437. https://doi.org/10. 1016/j.bcmd.2020.102437

Gao J, Tian Z, Yang X (2020) Breakthrough: Chloroquine phosphate has shown apparent efficacy in treatment of COVID-19 associated pneumonia in clinical studies. Bioscience trends. https://doi. org/10.5582/bst.2020.01047

Garcia-Revilla J, Deierborg T, Venero JL, Boza-Serrano A (2020) Hyperinflammation and Fibrosis in Severe COVID-19 Patients: Galectin-3, a Target Molecule to Consider [Perspective]. Front Immunol 11(2069). https://doi.org/10.3389/fimmu.2020.02069

George PM, Wells AU, Jenkins RG (2020) Pulmonary fibrosis and COVID-19: the potential role for antifibrotic therapy. Lancet Respir Med 8(8):807-815. https://doi.org/10.1016/S22132600(20)30225-3

Ghonim MA, Pyakurel K, Ibba SV, Al-Khami AA, Wang J, Rodriguez P, Rady HF, El-Bahrawy AH, Lammi MR, Mansy MS (2015a) PARP inhibition by olaparib or gene knockout blocks asthma-like manifestation in mice by modulating $\mathrm{CD} 4+\mathrm{T}$ cell function. $\mathrm{J}$ Transl Med 13(1):1-12. 10.1186/s12967-015-0583-0

Ghonim MA, Pyakurel K, Ibba SV, Wang J, Rodriguez P, Al-Khami AA, Lammi MR, Kim H, Zea AH, Davis C (2015b) PARP is activated in human asthma and its inhibition by olaparib blocks house dust mite-induced disease in mice. Clin Sci 129(11):951962. 10.1042/CS2015b0122

Giannetta E, Feola T, Gianfrilli D, Pofi R, Dall'Armi V, Badagliacca R, Barbagallo F, Lenzi A, Isidori AM (2014) Is chronic inhibition of phosphodiesterase type 5 cardioprotective and safe? A metaanalysis of randomized controlled trials. BMC Med 12(1):185. https://doi.org/10.1186/s12916-014-0185-3

Giorgi M, Cardarelli S, Ragusa F, Saliola M, Biagioni S, Poiana G, Naro F, Massimi M (2020) Phosphodiesterase Inhibitors: Could They Be Beneficial for the Treatment of COVID-19? Int J Mol Sci 21(15):5338. https://doi.org/10.3390/ijms21155338

Giovagnoni A (2020) Facing the COVID-19 emergency: we can and we do. Radiol Med 125(4):337-338. https://doi.org/10.1007/ s11547-020-01178-y

Gorbalenya AE, Baker SC, Baric RS, de Groot RJ, Drosten C, Gulyaeva AA, Haagmans BL, Lauber C, Leontovich AM, Neuman BW, Penzar D, Perlman S, Poon LLM, Samborskiy DV,
Sidorov IA, Sola I, Ziebuhr J, \& Coronaviridae Study Group of the International Committee on Taxonomy of, V. (2020). The species Severe acute respiratory syndrome-related coronavirus: classifying 2019-nCoV and naming it SARS-CoV-2. Nat Microbiol, 5(4), 536-544. https://doi.org/10.1038/ s41564-020-0695-z

Gordon CJ, Tchesnokov EP, Feng JY, Porter DP, Götte M (2020) The antiviral compound remdesivir potently inhibits RNA-dependent RNA polymerase from Middle East respiratory syndrome coronavirus. J Biol Chem 295(15):4773-4779. https://doi.org/10. 1074/jbc.AC120.013056

Griffin MO, Fricovsky E, Ceballos G, Villarreal F (2010) Tetracyclines: a pleitropic family of compounds with promising therapeutic properties. Review of the literature. Am J Physiol 299(3):C539C548. https://doi.org/10.1152/ajpcell.00047.2010

Grifoni A, Weiskopf D, Ramirez SI, Mateus J, Dan JM, Moderbacher CR, Rawlings SA, Sutherland A, Premkumar L, Jadi RS (2020) Targets of $\mathrm{T}$ cell responses to SARS-CoV-2 coronavirus in humans with COVID-19 disease and unexposed individuals. Cell. https://doi.org/10.1016/j.cell.2020.05.015

Güler HI, Tatar G, Yildiz O, Belduz AO, Kolayli S (2020) An investigation of ethanolic propolis extracts: Their potential inhibitor properties against ACE-II receptors for COVID-19 treatment by Molecular Docking Study. ScienceOpen PreHTMLs. https://doi. org/10.14293/S2199-1006.1.SOR-.PP5BWN4.v1

Guillot S, Delaval P, Brinchault G, Caulet-Maugendre S, Depince A, Lena H, Delatour B, Lagente V, Martin-Chouly C (2006) Increased extracellular matrix metalloproteinase inducer (EMMPRIN) expression in pulmonary fibrosis. Exp Lung Res 32(34):81-97. https://doi.org/10.1080/01902140600710512

Guo Y-R, Cao Q-D, Hong Z-S, Tan Y-Y, Chen S-D, Jin H-J, Tan K-S, Wang D-Y, Yan Y (2020) The origin, transmission and clinical therapies on coronavirus disease 2019 (COVID-19) outbreak-an update on the status. Milit Med Res 7(1):1-10. https://doi.org/ 10.1186/s40779-020-00240-0

Hadjicharalambous MR, Lindsay MA (2020) Idiopathic Pulmonary Fibrosis: Pathogenesis and the Emerging Role of Long NonCoding RNAs. Int J Mol Sci 21(2):524. https://doi.org/10.3390/ ijms 21020524

Hashem H (2020) IN Silico approach of some selected honey constituents as SARS-CoV-2 main protease (COVID-19) inhibitors. https://doi.org/10.14744/ejmo.2020.36102

Henehan M, Montuno M, De Benedetto A (2017) Doxycycline as an anti-inflammatory agent: updates in dermatology. J Eur Acad Dermatol Venereol 31(11):1800-1808. https://doi.org/10.1111/ jdv. 14345

Henry BM (2020) COVID-19, ECMO, and lymphopenia: a word of caution. Lancet Respir Med 8(4):e24. https://doi.org/10.1016/ S2213-2600(20)30119-3

Henry BM, Lippi G (2020) Poor survival with extracorporeal membrane oxygenation in acute respiratory distress syndrome (ARDS) due to coronavirus disease 2019 (COVID-19): Pooled analysis of early reports. J Crit Care. https://doi.org/10.1016/j. jcrc.2020.03.011

Heurich A, Hofmann-Winkler H, Gierer S, Liepold T, Jahn O, Pohlmann S (2014) TMPRSS2 and ADAM17 cleave ACE2 differentially and only proteolysis by TMPRSS 2 augments entry driven by the severe acute respiratory syndrome coronavirus spike protein. J Virol 88(2):1293-1307. https://doi.org/10.1128/JVI. 02202-13

Hoffmann M, Kleine-Weber H, Schroeder S, Kruger N, Herrler T, Erichsen S, Schiergens TS, Herrler G, Wu NH, Nitsche A, Muller MA, Drosten C, Pohlmann S (2020) SARS-CoV-2 cell entry depends on ACE2 and TMPRSS2 and is blocked by a clinically proven protease inhibitor. Cell 181(2):271-280 e278. https://doi. org/10.1016/j.cell.2020.02.052 
Hori JI, Zamboni DS, Carrão DB, Goldman GH, Berretta AA (2013) The inhibition of inflammasome by Brazilian propolis (EPP-AF). Evid Based Complement Altern Med 2013:418508. https://doi. org/10.1155/2013/418508

Hou L, Li M, Guo K, Wang W, Li B, Li J, Yuan Y (2020) First successful treatment of a COVID-19 pregnant woman with severe ARDS by combining early mechanical ventilation and ECMO. Heart Lung. https://doi.org/10.1016/j.hrtlng.2020.08.015

Humar A, McGilvray I, Phillips MJ, Levy GA (2004) Severe acute respiratory syndrome and the liver. Hepatology 39(2):291. https:// doi.org/10.1002/hep.20069

Isidori AM, Giannetta E, Pofi R, Venneri MA, Gianfrilli D, Campolo F, Mastroianni CM, Lenzi A, d'Ettorre G (2020) Targeting the NOcGMP-PDE5 pathway in COVID-19 infection. The DEDALO project. Andrology. https://doi.org/10.1111/andr.12837

Jia H (2016) Pulmonary Angiotensin-Converting Enzyme 2 (ACE2) and Inflammatory lung disease. Shock 46(3):239-248. https:// doi.org/10.1097/SHK.0000000000000633

Kaur U, Acharya K, Mondal R, Singh A, Saso L, Chakrabarti S, Chakrabarti SS (2020a) Should ACE2 be given a chance in COVID-19 therapeutics: A semi-systematic review of strategies enhancing ACE2. Eur J Pharmacol 887:173545. 10.1016/j. ejphar.2020a.173545

Kaur U, Chakrabarti SS, Ojha B, Pathak BK, Singh A, Saso L, Chakrabarti S (2020b) Targeting host cell proteases to prevent SARSCoV-2 invasion. Curr Drug Targets. https://doi.org/10.2174/ 1389450121666200924113243

Keech C, Albert G, Cho I, Robertson A, Reed P, Neal S, Plested JS, Zhu M, Cloney-Clark S, Zhou H, Smith G, Patel N, Frieman MB, Haupt RE, Logue J, McGrath M, Weston S, Piedra PA, Desai C, Callahan K, Lewis M, Price-Abbott P, Formica N, Shinde V, Fries L, Lickliter JD, Griffin P, Wilkinson B, Glenn GM (2020) Phase 1-2 Trial of a SARS-CoV-2 Recombinant Spike Protein Nanoparticle Vaccine. N Engl J Med 383(24):2320-2332. https:// doi.org/10.1056/NEJMoa2026920

Kendall RT, Feghali-Bostwick CA (2014) Fibroblasts in fibrosis: novel roles and mediators. Front Pharmacol 5:123. https://doi.org/10. 3389/fphar.2014.00123

Kim HW, Capaccione KM, Li G, Luk L, Widemon RS, Rahman O, Beylergil V, Mitchell R, D’Souza BM, Leb JS, Dumeer S, Bentley-Hibbert S, Liu M, Jambawalikar S, Austin JHM, Salvatore $\mathrm{M}(2020)$ The role of initial chest X-ray in triaging patients with suspected COVID-19 during the pandemic. Emerg Radiol 27(6):617-621. https://doi.org/10.1007/s10140-020-01808-y

Kim JH, Suk MH, Yoon DW, Kim HY, Jung KH, Kang EH, Lee SY, Lee SY, Suh IB, Shin C (2008) Inflammatory and transcriptional roles of poly (ADP-ribose) polymerase in ventilator-induced lung injury. Crit Care 12(4):1-9. https://doi.org/10.1186/cc6995

Kinoshita T, Goto T (2019) Molecular mechanisms of pulmonary fibrogenesis and its progression to lung cancer: a review. Int $\mathrm{J}$ Mol Sci. https://doi.org/10.3390/ijms20061461

Kobie N (2020) How CRISPR is helping scientists create a better coronavirus test. Publishing WIERD. https://www.wired.co.uk/artic le/crispr-coronavirus-test. Accessed 01 May 2021

Kolahian S, Fernandez IE, Eickelberg O, Hartl D (2016) Immune mechanisms in pulmonary fibrosis. Am J Respir Cell Mol Biol 55(3):309-322. https://doi.org/10.1165/rcmb.2016-0121TR

Kovak MR, Saraswati S, Schoen DJ, Diekman AB (2014) Investigation of galectin-3 function in the reproductive tract by identification of binding ligands in human seminal plasma. Am J Reprod Immunol 72(4):403-412. https://doi.org/10.1111/aji.12273

Kuba K, Imai Y, Penninger JM (2006) Angiotensin-converting enzyme 2 in lung diseases. Curr Opin Pharmacol 6(3):271-276. https:// doi.org/10.1016/j.coph.2006.03.001

Kumar V, Dhanjal JK, Kaul SC, Wadhwa R, Sundar D (2020) Withanone and caffeic acid phenethyl ester are predicted to interact with main protease (Mpro) of SARS-CoV-2 and inhibit its activity. J Biomol Struct Dyn 1-13. https://doi.org/10.1080/ 07391102.2020 .1772108

Kuo K-W, Chang L-S, Chang C-C (1995) The structural loop II of cobrotoxin is the main binding region for $\mathrm{nAChR}$ and epitope in the region is conformation-dependent. J Biochem 117(2):438-442. https://doi.org/10.1093/jb/117.2.438

Laboratory. DLBN (2020) Scientists aim gene-targeting breakthrough against COVID-19: Cellular delivery system could be missing link in battle against SARS-CoV-2. Publishing Sciencedaily. www.sciencedaily.com/releases/2020/06/20060 4095651.htm. Accessed 01 May 2021

Lamb LE, Bartolone SN, Ward E, Chancellor MB (2020) Rapid detection of novel coronavirus/Severe Acute Respiratory Syndrome Coronavirus 2 (SARS-CoV-2) by reverse transcription-loop-mediated isothermal amplification. PLoS ONE 15(6):e0234682. https://doi.org/10.1371/journal.pone.0234682

Lechowicz K, Drozdzal S, Machaj F, Rosik J, Szostak B, ZeganBaranska M, Biernawska J, Dabrowski W, Rotter I, Kotfis K (2020) COVID-19: the potential treatment of pulmonary fibrosis associated with SARS-CoV-2 infection. J Clin Med. https:// doi.org/10.3390/jcm9061917

Leng Z, Zhu R, Hou W, Feng Y, Yang Y, Han Q, Shan G, Meng F, Du D, Wang S (2020) Transplantation of ACE2-mesenchymal stem cells improves the outcome of patients with COVID-19 pneumonia. Aging disease 11(2):216. https://doi.org/10.14336/ AD.2020.0228

Leung JM, Yang CX, Tam A, Shaipanich T, Hackett TL, Singhera GK, Dorscheid DR, Sin DD (2020) ACE-2 expression in the small airway epithelia of smokers and COPD patients: implications for COVID-19. Eur Respir J. https://doi.org/10.1183/ 13993003.00688-2020

Li C, Ren L (2020) Recent progress on the diagnosis of 2019 Novel Coronavirus. Transbound Emerg Dis 67(4):1485-1491. https:// doi.org/10.1111/tbed.13620

Li X, Guo Z, Li B, Zhang X, Tian R, Wu W, Zhang Z, Lu Y, Chen N, Clifford SP (2020) Extracorporeal membrane oxygenation for coronavirus disease 2019 in Shanghai, China. Asaio J 66(5):475. https://doi.org/10.1097/MAT.0000000000001172

Li Z, Niu S, Guo B, Gao T, Wang L, Wang Y, Wang L, Tan Y, Wu J, Hao J (2020) Stem cell therapy for COVID-19, ARDS and pulmonary fibrosis. Cell Prolif 53(12):e12939. https://doi.org/ 10.1111/cpr.12939

Liao M, Liu Y, Yuan J, Wen Y, Xu G, Zhao J, Cheng L, Li J, Wang X, Wang F (2020) Single-cell landscape of bronchoalveolar immune cells in patients with COVID-19. Nat Med. https:// doi.org/10.1038/s41591-020-0901-9

Liaudet L, Pacher P, Mabley JG, Virág L, Soriano FG, HASKÓ GR, Szabó C (2002) Activation of poly (ADP-Ribose) polymerase-1 is a central mechanism of lipopolysaccharide-induced acute lung inflammation. Am J Respir Crit Care Med 165(3):372377. https://doi.org/10.1164/ajrccm.165.3.2106050

Lin F, Reid PF, Qin Z-h (2020) Cobrotoxin could be an effective therapeutic for COVID-19. Acta Pharmacol Sin 41(9):1258-1260. https://doi.org/10.1038/s41401-020-00501-7

Liu RM, Desai LP (2015) Reciprocal regulation of TGF-beta and reactive oxygen species: a perverse cycle for fibrosis. Redox Biol 6:565-577. https://doi.org/10.1016/j.redox.2015.09.009

Lo MK, Jordan R, Arvey A, Sudhamsu J, Shrivastava-Ranjan P, Hotard AL, Flint M, McMullan LK, Siegel D, Clarke MO (2017) GS-5734 and its parent nucleoside analog inhibit Filo-, Pneumo-, and Paramyxoviruses. Scientific reports 7:43395. https://doi.org/10.1038/srep43395

Long C, Xu H, Shen Q, Zhang X, Fan B, Wang C, Zeng B, Li Z, Li X, Li H (2020) Diagnosis of the Coronavirus disease 
(COVID-19): rRT-PCR or CT? Eur J Radiol 126:108961. https://doi.org/10.1016/j.ejrad.2020.108961

Long M, Beckwith K, Do P, Mundy BL, Gordon A, Lehman AM, Maddocks KJ, Cheney C, Jones JA, Flynn JM (2017) Ibrutinib treatment improves $\mathrm{T}$ cell number and function in CLL patients. J Clin Investig 127(8):3052-3064. https://doi.org/10. 1172/JCI89756

Mabley J, Jagtap P, Perretti M, Getting SJ, Salzman AL, Virag L, Szabo E, Soriano F, Liaudet L, Abdelkarim G (2001) Antiinflammatory effects of a novel, potent inhibitor of poly (ADPribose) polymerase. Inflamm Res 50(11):561-569. https://doi. org/10.1007/PL00000234

Machado JL, Assunção AKM, da Silva MCP, Reis ASd, Costa GC, Arruda DdS, Rocha BA, Vaz MMdOLL, Paes AMdA, Guerra RNM, Berretta AA, Nascimento FRFd (2012) Brazilian Green Propolis: Anti-Inflammatory Property by an Immunomodulatory Activity. Evid Based Complement Alternat Med 2012:157652. https://doi.org/10.1155/2012/157652

Mandolesi M, Sheward DJ, Hanke L, Ma J, Pushparaj P, Vidakovics LP, Kim C, Loré K, Dopico XC, Coquet JM (2020) SARS$\mathrm{CoV}-2$ protein subunit vaccination elicits potent neutralizing antibody responses. BioRxiv. https://doi.org/10.1101/2020.07. 31.228486

Martín M, Macías M, Escames G, León J, Acuña-Castroviejo D (2000) Melatonin but not vitamins $\mathrm{C}$ and $\mathrm{E}$ maintains glutathione homeostasis in t-butyl hydroperoxide-induced mitochondrial oxidative stress. FASEB J 14(12):1677-1679. https://doi.org/10.1096/fj. 99-0865fje

Maruta H, He H (2020) PAK1-blockers: potential therapeutics against COVID-19. Med Drug Discov. https://doi.org/10.1016/j.medidd. 2020.100039

McGee MC, August A, Huang W (2020) BTK/ITK dual inhibitors: Modulating immunopathology and lymphopenia for COVID19 therapy. J Leukoc Biol. https://doi.org/10.1002/JLB.5COVR 0620-306R

Mehta P, McAuley DF, Brown M, Sanchez E, Tattersall RS, Manson JJ, Collaboration HAS (2020) COVID-19: consider cytokine storm syndromes and immunosuppression. Lancet 395(10229): 1033. https://doi.org/10.1016/S0140-6736(20)30628-0

Meng H, Xiong R, He R, Lin W, Hao B, Zhang L, Lu Z, Shen X, Fan T, Jiang W, Yang W, Li T, Chen J, Geng Q (2020) CT imaging and clinical course of asymptomatic cases with COVID-19 pneumonia at admission in Wuhan, China. J Infect 81(1):e33-e39. https://doi.org/10.1016/j.jinf.2020.04.004

Meo S, Klonoff D, Akram J (2020) Efficacy of chloroquine and hydroxychloroquine in the treatment of COVID-19. Eur Rev Med Pharmacol Sci 24(8):4539-4547. https://doi.org/10.26355/eurrev_ 202004_21038

Merad M, Martin JC (2020) Pathological inflammation in patients with COVID-19: a key role for monocytes and macrophages. Nat Rev Immunol. https://doi.org/10.1038/s41577-020-0331-4

Moheimani F, Koops J, Williams T, Reid AT, Hansbro PM, Wark PA, Knight DA (2018) Influenza A virus infection dysregulates the expression of microRNA-22 and its targets; CD147 and HDAC4, in epithelium of asthmatics. Respir Res 19(1):145. https://doi. org/10.1186/s12931-018-0851-7

Mulligan MJ, Lyke KE, Kitchin N, Absalon J, Gurtman A, Lockhart S, Neuzil K, Raabe V, Bailey R, Swanson KA (2020) Phase I/II study of COVID-19 RNA vaccine BNT162b1 in adults. Nature 586(7830):589-593. https://doi.org/10.1038/s41586-020-2639-4

Mummery RS, Rider CC (2000) Characterization of the heparin-binding properties of IL-6. J Immunol 165(10):5671-5679. https:// doi.org/10.4049/jimmunol.165.10.5671

Neidleman J, Luo X, Frouard J, Xie G, Gill G, Stein ES, McGregor M, Ma T, George A, Kosters A (2020) SARS-CoV-2-specific T cells exhibit unique features reflecting robust helper function, lack of terminal differentiation, and high proliferative potential. BioRxiv. https://doi.org/10.1016/j.xcrm.2020.100081

Neri E, Miele V, Coppola F, Grassi R (2020) Use of CT and artificial intelligence in suspected or COVID-19 positive patients: statement of the Italian Society of Medical and Interventional Radiology. Radiol Med 125(5):505-508. https://doi.org/10.1007/ s11547-020-01197-9

Nile SH, Nile A, Qiu J, Li L, Jia X, Kai G (2020) COVID-19: Pathogenesis, cytokine storm and therapeutic potential of interferons. Cytokine Growth Factor Rev. https://doi.org/10.1016/j.cytogfr. 2020.05.002

Noor A, Najmi M, Bukhtiar S (2011) Effect of montelukast on bradykinin-induced contraction of isolated tracheal smooth muscle of guinea pig. Indian J Pharmacol 43(4):445. https://doi.org/10. 4103/0253-7613.83119

Ojo AS, Balogun SA, Williams OT, Ojo OS (2020) Pulmonary fibrosis in covid-19 survivors: predictive factors and risk reduction strategies. Pulm Med 2020:6175964. https://doi.org/10.1155/ 2020/6175964

Okamori S, Lee H, Kondo Y, Akiyama Y, Kabata H, Kaneko Y, Ishii M, Hasegawa N, Fukunaga K (2020) Coronavirus disease 2019-associated rapidly progressive organizing pneumonia with fibrotic feature: two case reports. Med (Baltim) 99(35):e21804. https://doi.org/10.1097/MD.0000000000021804

Omar S, Bouziane I, Bouslama Z, Djemel A (2020) In-silico identification of potent inhibitors of COVID-19 main protease (Mpro) and angiotensin converting enzyme 2 (ACE2) from natural products: quercetin, hispidulin, and cirsimaritin exhibited better potential inhibition than hydroxy-chloroquine against covid-19 main protease active site and acE2. ChemRxiv. https://doi.org/10.26434/ chemrxiv.12181404.v1

Pagano A, Métrailler-Ruchonnet I, Aurrand-Lions M, Lucattelli M, Donati Y, Argiroffo CB (2007) Poly (ADP-ribose) polymerase-1 (PARP-1) controls lung cell proliferation and repair after hyperoxia-induced lung damage. Am J Physiol 293(3):L619-L629. https://doi.org/10.1152/ajplung.00037.2007

Parimon T, Yao C, Stripp BR, Noble PW, Chen P (2020) Alveolar epithelial type ii cells as drivers of lung fibrosis in idiopathic pulmonary fibrosis. Int J Mol Sci. https://doi.org/10.3390/ijms2 1072269

Phillips JE (2020) Inhaled Phosphodiesterase 4 (PDE4) inhibitors for inflammatory respiratory diseases. Front Pharmacol 11:259. https://doi.org/10.3389/fphar.2020.00259

Phillips JM, Gallagher T, Weiss SR (2017) Neurovirulent murine coronavirus JHM. J Virol, SD uses cellular zinc metalloproteases for virus entry and cell-cell fusion. https://doi.org/10.1128/JVI. 01564-16

Pizzorno A, Padey B, Julien T, Trouillet-Assant S, Traversier A, Errazuriz-Cerda E, Lescure F (2020) Characterization and treatment of SARS-CoV-2 in nasal and bronchial human airway epithelia. Cell Rep Med 1:100059. https://doi.org/10.1016/j.xcrm.2020. 100059

Polak SB, Van Gool IC, Cohen D, Jan H, van Paassen J (2020) A systematic review of pathological findings in COVID-19: a pathophysiological timeline and possible mechanisms of disease progression. Mod Pathol 33(11):2128-2138. https://doi.org/10. 1038/s41379-020-0603-3

Qin C, Zhou L, Hu Z, Zhang S, Yang S, Tao Y, Xie C, Ma K, Shang K, Wang W, Tian DS (2020) Dysregulation of immune response in patients with COVID-19 in Wuhan, China. Clin Infect Dis Off Publ Infect Dis Soc Am 71(15):762-768. https://doi.org/10. 1093/cid/ciaa248

Reyfman PA, Walter JM, Joshi N, Anekalla KR, McQuattie-Pimentel AC, Chiu S, Fernandez R, Akbarpour M, Chen C-I, Ren Z (2019) Single-cell transcriptomic analysis of human lung provides insights into the pathobiology of pulmonary fibrosis. Am 
J Respir Crit Care Med 199(12):1517-1536. https://doi.org/10. 1164/rccm.201712-2410OC

Rousan LA, Elobeid E, Karrar M, Khader Y (2020) Chest X-ray findings and temporal lung changes in patients with COVID-19 pneumonia. BMC Pulm Med 20(1):245. https://doi.org/10.1186/ s12890-020-01286-5

Rubin GD, Ryerson CJ, Haramati LB, Sverzellati N, Kanne JP, Raoof S, Schluger NW, Volpi A, Yim JJ, Martin IBK, Anderson DJ, Kong C, Altes T, Bush A, Desai SR, Goldin J, Goo JM, Humbert M, Inoue Y, Kauczor HU, Luo F, Mazzone PJ, Prokop M, Remy-Jardin M, Richeldi L, Schaefer-Prokop CM, Tomiyama N, Wells AU, Leung AN (2020) The role of chest imaging in patient management during the covid-19 pandemic: a multinational consensus statement from the Fleischner Society. Chest 158(1):106-116. https://doi.org/10.1016/j.chest.2020.04.003

Sahu B, Narota A, Naura AS (2020) Pharmacological inhibition of poly (ADP-ribose) polymerase by olaparib, prevents acute lung injury associated cognitive deficits potentially through suppression of inflammatory response. Eur J Pharmacol. https://doi.org/ 10.1016/j.ejphar.2020.173091

Salehi S, Abedi A, Balakrishnan S, Gholamrezanezhad A (2020) Coronavirus Disease 2019 (COVID-19): A Systematic Review of Imaging Findings in 919 Patients. AJR Am J Roentgenol 215(1):87-93. https://doi.org/10.2214/AJR.20.23034

Self WH, Courtney DM, McNaughton CD, Wunderink RG, Kline JA (2013) High discordance of chest X-ray and computed tomography for detection of pulmonary opacities in ED patients: implications for diagnosing pneumonia. Am J Emerg Med 31(2):401405. https://doi.org/10.1016/j.ajem.2012.08.041

Selman M, King TE, Pardo A, American Thoracic S, Respiratory ES, American College of Chest P (2001) Idiopathic pulmonary fibrosis: prevailing and evolving hypotheses about its pathogenesis and implications for therapy. Ann Intern Med 134(2):136-151. https://doi.org/10.7326/0003-4819-134-2-200101160-00015

Selman M, Pardo A (2006) Role of epithelial cells in idiopathic pulmonary fibrosis: from innocent targets to serial killers. Proc Am Thorac Soc 3(4):364-372. https://doi.org/10.1513/pats. 200601-003TK

Selman M, Pardo A (2020) The leading role of epithelial cells in the pathogenesis of idiopathic pulmonary fibrosis. Cell Signal 66:109482. https://doi.org/10.1016/j.cellsig.2019.109482

Sethi GS, Sharma S, Naura AS (2019) PARP inhibition by olaparib alleviates chronic asthma-associated remodeling features via modulating inflammasome signaling in mice. IUBMB Life 71(7):1003-1013. https://doi.org/10.1002/iub.2048

Sgalla G, Iovene B, Calvello M, Ori M, Varone F, Richeldi L (2018) Idiopathic pulmonary fibrosis: pathogenesis and management. Respir Res 19(1):32. https://doi.org/10.1186/s12931-018-0730-2

Shannon JM, Hyatt BA (2004) Epithelial-mesenchymal interactions in the developing lung. Annu Rev Physiol 66:625-645. https://doi. org/10.1146/annurev.physiol.66.032102.135749

Sheahan TP, Sims AC, Graham RL, Menachery VD, Gralinski LE, Case JB, Leist SR, Pyrc K, Feng JY, Trantcheva I (2017) Broadspectrum antiviral GS-5734 inhibits both epidemic and zoonotic coronaviruses. Sci Transl Med. https://doi.org/10.1126/scitr anslmed.aal3653

Sheahan TP, Sims AC, Leist SR, Schäfer A, Won J, Brown AJ, Montgomery SA, Hogg A, Babusis D, Clarke MO (2020) Comparative therapeutic efficacy of remdesivir and combination lopinavir, ritonavir, and interferon beta against MERS-CoV. Nat Commun 11(1):1-14. https://doi.org/10.1038/s41467-019-13940-6

Shimizu T, Takeshita Y, Takamori Y, Kai H, Sawamura R, Yoshida H, Watanabe W, Tsutsumi A, Park YK, Yasukawa K (2011) Efficacy of Brazilian propolis against herpes simplex virus type 1 infection in mice and their modes of antiherpetic efficacies.
Evid Based Complement Altern Med. https://doi.org/10.1155/ 2011/976196

Shrikrishna D, Astin R, Kemp PR, Hopkinson NS (2012) Renin-angiotensin system blockade: a novel therapeutic approach in chronic obstructive pulmonary disease. Clin Sci (Lond) 123(8):487-498. https://doi.org/10.1042/CS20120081

Singh AK, Singh A, Singh R, Misra A (2020) Remdesivir in COVID19: a critical review of pharmacology, pre-clinical and clinical studies. Diabete Metab Syndrome. https://doi.org/10.1016/j.dsx. 2020.05.018

Skeggs LT, Dorer FE, Levine M, Lentz KE, Kahn JR (1980) The biochemistry of the renin-angiotensin system. Adv Exp Med Biol 130:1-27. https://doi.org/10.1007/978-1-4615-9173-3_1

Sodhi M, Etminan M (2020) Therapeutic potential for tetracyclines in the treatment of COVID-19. Pharmacotherapy 40(5):487-488. https://doi.org/10.1002/phar.2395

Solouki S, August A, Huang W (2019) Non-receptor tyrosine kinase signaling in autoimmunity and therapeutic implications. Pharmacol Ther 201:39-50. https://doi.org/10.1016/j.pharmthera. 2019.05.008

South AM, Diz DI, Chappell MC (2020) COVID-19, ACE2, and the cardiovascular consequences. Am J Physiol Heart Circ Physiol 318(5):H1084-H1090. https://doi.org/10.1152/ajpheart.00217. 2020

Straiton J (2020) CRISPR vs COVID-19: how can gene editing help beat a virus? BioTechniques 69(5):327-329. https://doi.org/10. 2144/btn-2020-0145

Sun Y, Peng I, Webster JD, Suto E, Lesch J, Wu X, Senger K, Francis G, Barrett K, Collier JL (2015) Inhibition of the kinase ITK in a mouse model of asthma reduces cell death and fails to inhibit the inflammatory response. Sci Signaling 8(405):ra122-ra122. https://doi.org/10.1126/scisignal.aab0949

Sundarakrishnan A, Chen Y, Black LD, Aldridge BB, Kaplan DL (2018) Engineered cell and tissue models of pulmonary fibrosis. Adv Drug Deliv Rev 129:78-94. https://doi.org/10.1016/j.addr. 2017.12.013

Tai W, He L, Zhang X, Pu J, Voronin D, Jiang S, Zhou Y, Du L (2020) Characterization of the receptor-binding domain (RBD) of 2019 novel coronavirus: implication for development of RBD protein as a viral attachment inhibitor and vaccine. Cell Mol Immunol 17(6):613-620. https://doi.org/10.1038/s41423-020-0400-4

Tan WSD, Liao W, Zhou S, Mei D, Wong WF (2018) Targeting the renin-angiotensin system as novel therapeutic strategy for pulmonary diseases. Curr Opin Pharmacol 40:9-17. https://doi.org/ 10.1016/j.coph.2017.12.002

Tay MZ, Poh CM, Rénia L, MacAry PA, Ng LF (2020) The trinity of COVID-19: immunity, inflammation and intervention. Nat Rev Immunol. https://doi.org/10.1038/s41577-020-0311-8

Tian J-H, Patel N, Haupt R, Zhou H, Weston S, Hammond H, Lague J, Portnoff AD, Norton J, Guebre-Xabier M (2020) SARS-CoV-2 spike glycoprotein vaccine candidate NVX-CoV2373 elicits immunogenicity in baboons and protection in mice. BioRxiv. https://doi.org/10.1038/s41467-020-20653-8

Tipnis SR, Hooper NM, Hyde R, Karran E, Christie G, Turner AJ (2000) A human homolog of angiotensin-converting enzyme. Cloning and functional expression as a captopril-insensitive carboxypeptidase. J Biol Chem 275(43):33238-33243. https://doi. org/10.1074/jbc.M002615200

Uccelli A, de Rosbo NK (2015) The immunomodulatory function of mesenchymal stem cells: mode of action and pathways. Ann N Y Acad Sci 1351(1):114-126. https://doi.org/10.1111/nyas.12815

Ulrich H, Pillat MM (2020) CD147 as a target for COVID-19 treatment: suggested effects of azithromycin and stem cell engagement. Stem Cell Rev Rep 16(3):434-440. https://doi.org/10. 1007/s12015-020-09976-7 
Upagupta C, Shimbori C, Alsilmi R, Kolb M (2018) Matrix abnormalities in pulmonary fibrosis. Eur Respir Rev. https://doi.org/ 10.1183/16000617.0033-2018

Vandenberg O, Martiny D, Rochas O, van Belkum A, Kozlakidis Z (2020) Considerations for diagnostic COVID-19 tests. Nat Rev Microbiol. https://doi.org/10.1038/s41579-020-00461-z

Vickers C, Hales P, Kaushik V, Dick L, Gavin J, Tang J, Godbout K, Parsons T, Baronas E, Hsieh F, Acton S, Patane M, Nichols A, Tummino P (2002) Hydrolysis of biological peptides by human angiotensin-converting enzyme-related carboxypeptidase. J Biol Chem 277(17):14838-14843. https://doi.org/10.1074/jbc.M2005 81200

Vincent MJ, Bergeron E, Benjannet S, Erickson BR, Rollin PE, Ksiazek TG, Seidah NG, Nichol ST (2005) Chloroquine is a potent inhibitor of SARS coronavirus infection and spread. Virol J 2(1):1-10. https://doi.org/10.1186/1743-422X-2-69

Virág L, Bai P, Bak I, Pacher P, Mabley J, Liaudet L, Bakondi E, Gergely P, Kollai M, Szabo C (2004) Effects of poly (ADPribose) polymerase inhibition on inflammatory cell migration in a murine model of asthma. Med Sci Monitor 10(3):77-83

Wang D, Hu B, Hu C, Zhu F, Liu X, Zhang J, Wang B, Xiang H, Cheng Z, Xiong Y (2020) Clinical characteristics of 138 hospitalized patients with 2019 novel coronavirus-infected pneumonia in Wuhan, China. Jama 323(11):1061-1069. https://doi.org/10. 1001/jama.2020.1585

Wang K, Chen W, Zhang Z, Deng Y, Lian J-Q, Du P, Wei D, Zhang Y, Sun X-X, Gong L (2020) CD147-spike protein is a novel route for SARS-CoV-2 infection to host cells. Signal Transduct Target Therapy 5(1):1-10. https://doi.org/10.1038/s41392-020-00426-x

Wang L, Wang Y, Yang T, Guo Y, Sun T (2015) Angiotensin-converting enzyme 2 attenuates bleomycin-induced lung fibrosis in mice. Cell Physiol Biochem 36(2):697-711. https://doi.org/10. 1159/000430131

Weber AN, Bittner Z, Liu X, Dang T-M, Radsak MP, Brunner C (2017) Bruton's tyrosine kinase: an emerging key player in innate immunity. Front Immunol 8:1454. https://doi.org/10.3389/fimmu.2017. 01454

Weber KT (1997) Fibrosis, a common pathway to organ failure: angiotensin II and tissue repair. Semin Nephrol 17(5):467-491

Weiskopf D, Schmitz K, Raadsen M, Grifoni A, Okba N, Endeman H, van Gorp E (2020) Phenotype and kinetics of SARS-CoV2-specific T cells in COVID-19 patients with acute respiratory distress syndrome. Sci Immunol 5:2071. https://doi.org/10.1126/ sciimmunol.abd2071

Wigen J, Lofdahl A, Bjermer L, Elowsson-Rendin L, WestergrenThorsson G (2020) Converging pathways in pulmonary fibrosis and Covid-19 - The fibrotic link to disease severity. Respir Med X 2:100023. https://doi.org/10.1016/j.yrmex.2020.100023

Wipff PJ, Rifkin DB, Meister JJ, Hinz B (2007) Myofibroblast contraction activates latent TGF-beta1 from the extracellular matrix. J Cell Biol 179(6):1311-1323. https://doi.org/10.1083/jcb.20070 4042

Wong HYF, Lam HYS, Fong AH, Leung ST, Chin TW, Lo CSY, Lui MM, Lee JCY, Chiu KW, Chung TW, Lee EYP, Wan EYF, Hung IFN, Lam TPW, Kuo MD, Ng MY (2020) Frequency and distribution of chest radiographic findings in patients positive for COVID-19. Radiology 296(2):E72-E78. https://doi.org/10.1148/ radiol.2020201160

Wu A, Chik S, Chan A, Li Z, Tsang K, Li W (2003) Anti-inflammatory effects of high-dose montelukast in an animal model of acute asthma. Clin Exp Allergy 33(3):359-366. https://doi.org/10. 1046/j.1365-2222.2003.01615.x

Wynn TA (2011) Integrating mechanisms of pulmonary fibrosis. J Exp Med 208(7):1339-1350. https://doi.org/10.1084/jem.20110551
Xu J-W, Ikeda K, Kobayakawa A, Ikami T, Kayano Y, Mitani T, Yamori Y (2005) Downregulation of Rac1 activation by caffeic acid in aortic smooth muscle cells. Life Sci 76(24):2861-2872. https://doi.org/10.1016/j.lfs.2004.11.015

Yan R, Zhang Y, Guo Y, Xia L, Zhou Q (2020) Structural basis for the recognition of the 2019-nCoV by human ACE2. BioRxiv. https:// doi.org/10.1101/2020.02.19.956946

Yao X, Ye F, Zhang M, Cui C, Huang B, Niu P, Liu X, Zhao L, Dong E, Song C, Zhan S, Lu R, Li H, Tan W, Liu D (2020) In vitro antiviral activity and projection of optimized dosing design of hydroxychloroquine for the treatment of severe acute respiratory syndrome coronavirus 2 (SARS-CoV-2). Clin Infect Dis Off Publ Infect Dis Soc Am 71(15):732-739. https://doi.org/10.1093/cid/ ciaa237

Ye Z, Zhang Y, Wang Y, Huang Z, Song B (2020) Chest CT manifestations of new coronavirus disease 2019 (COVID-19): a pictorial review. Eur Radiol 30(8):4381-4389. https://doi.org/10.1007/ s00330-020-06801-0

Yin JL, Wu Y, Yuan ZW, Gao XH, Chen HD (2020) Advances in scarless foetal wound healing and prospects for scar reduction in adults. Cell Prolif 53(11):e12916. https://doi.org/10.1111/cpr. 12916

Yoon SH, Lee KH, Kim JY, Lee YK, Ko H, Kim KH, Park CM, Kim YH (2020) Chest radiographic and CT findings of the 2019 Novel Coronavirus Disease (COVID-19): analysis of nine patients treated in Korea. Korean J Radiol 21(4):494-500. https://doi. org/10.3348/kjr.2020.0132

Yoshikawa T, Hill T, Li K, Peters CJ, Tseng C-TK (2009) Severe acute respiratory syndrome (SARS) coronavirus-induced lung epithelial cytokines exacerbate SARS pathogenesis by modulating intrinsic functions of monocyte-derived macrophages and dendritic cells. J Virol 83(7):3039-3048. https://doi.org/10.1128/ JVI.01792-08

Yuan B, Yang R, Ma Y, Zhou S, Zhang X, Liu Y (2017) A systematic review of the active saikosaponins and extracts isolated from Radix Bupleuri and their applications. Pharm Biol 55(1):620635. https://doi.org/10.1080/13880209.2016.1262433

Zakeri B, Wright GD (2008) Chemical biology of tetracycline antibiotics. Biochem Cell Biol 86(2):124-136. https://doi.org/10.1139/ O08-002

Zhang H, Shang W, Liu Q, Zhang X, Zheng M, Yue M (2020) Clinical characteristics of 194 cases of COVID-19 in Huanggang and Taian, China. Infection 48(5):687-694. https://doi.org/10.1007/ s15010-020-01440-5

Zhang J, Gharizadeh B, Lu D, Yue J, Yu M, Liu Y, Zhou M (2020) Navigating the pandemic response life cycle: molecular diagnostics and immunoassays in the context of COVID-19 management. IEEE Rev Biomed Eng. https://doi.org/10.1109/RBME. 2020.2991444

Zhang L, Feng X, Zhang D, Jiang C, Mei H, Wang J, Zhang C, Li H, Xia X, Kong S (2020) Deep vein thrombosis in hospitalized patients with coronavirus disease 2019 (COVID-19) in Wuhan, China: prevalence, risk factors, and outcome. Circulation. https:// doi.org/10.1161/CIRCULATIONAHA.120.046702

Zhou R, To KK-W, Wong Y-C, Liu L, Zhou B, Li X, Huang H, Mo Y, Luk T-Y, Lau TT-K (2020) Acute SARS-CoV-2 infection impairs dendritic cell and T cell responses. Immunity 53(4):864-877. e865. https://doi.org/10.1016/j.immuni.2020.07.026

Publisher's Note Springer Nature remains neutral with regard to jurisdictional claims in published maps and institutional affiliations. 